The Development of Agencies at EU and National Levels:

Conceptual Analysis and Proposals for Reform

Professor Damien Geradin

BAT. B31 Faculté de Droit

Boulevard du Rectorat, 7

4000 Liege - Belgium

D.geradin@ulg.ac.be

Nicolas Petit

BAT. B31 Faculté de Droit

Boulevard du Rectorat, 7

4000 Liege - Belgium

Nicolas.Petit@ulg.ac.be

http://www.ulg.ac.be/ieje 


\section{Introduction}

\section{The National Regulatory Authorities (NRAs)}

1. The development of regulatory agencies at the national level

2. Review of the institutional regulatory parameters

2.1 Centralization vs. decentralization

2.2 Homogeneity vs. diversity

2.3 Compliance with the principles of good governance

2.3.1 The requirement of independence

2.3.2 The requirement of accountability

2.3.3 Transparency

2.3.4 Participation

3. Fine-tuning the institutional regulatory parameters

3.1 The level of regulation in network industries

3.2 Optimal level of homogeneity among NRAs

3.3 Principles of good governance

\section{The European Agencies (EAs)}

1. The formation of EAs at the EC level

2. Review of the institutional regulatory parameters

2.1 Decentralization vs. centralization

2.2 Homogeneity vs. diversity

2.2.1 Common Features of the EAs

2.2.2 The different types of EAs - functional typology

2.2.3 The Communication of the Commission on a framework for regulatory agencies

2.2.4 Our proposed classification

2.3 Principles of good governance

2.3.1 Independence

2.3.2 Lack of accountability

Judicial Accountability

Financial Accountability

Political Accountability

'Performance' Accountability

2.3.3 Lack of transparency

2.3.4 Lack of participation

3. Fine tuning the institutional regulatory parameters for EAs

3.1 Improving the test for choosing to form EC wide agencies

3.2 The need for more homogeneity

3.3 Improving compliance with principles of good governance

\section{Conclusion}




\title{
The Development of Agencies at EU and National Levels: Conceptual Analysis and Proposals for Reform
}

\author{
Damien Geradin* and Nicolas Petit **
}

\section{Introduction}

Over the last ten years, one has witnessed a considerable expansion of agencies in the European Community (hereafter, the "EC"). ${ }^{1}$ This expansion can be observed at the national level where a large number of regulatory agencies (hereafter, the "NRAs") have been created in response to the liberalization directives adopted in the field of network industries (telecommunications, energy, rail etc.), as well as in response to domestic policies in a variety of economic and social areas. ${ }^{2}$ It can also be witnessed at the EC level where the number of agencies (hereafter, the "EAs") has increased from four in 1993 to fifteen in 2003. Only this year, the Commission has proposed the creation of three new agencies. ${ }^{3}$ The EC's appetite for creating new agencies seems limitless and no one knows exactly how many EAs will be in existence ten years from now.

The creation of NRAs and EAs under the impulsion of EC law generates a large number of interesting legal issues and the literature on such bodies is abundant. ${ }^{4}$ Perhaps, the

\footnotetext{
* Professor of Law and Director, Institute for European Legal Studies, University of Liège. Professor at the College of Europe and Research Director of the Global Competition Law Centre (GCLC), Bruges.

** Research fellow and doctoral candidate, Institute for European Legal Studies, University of Liège. The present study has benefited from financial support from the Interuniversity Poles of Attraction Program P5/32 initiated by the Belgian State, Prime Minister's Office - Federal Office for Scientific, Technical and Cultural Affairs.

${ }^{1}$ Agencies can be referred to as a "variety of organizations that perform functions of a governmental nature, and which often exist outside the normal departmental framework of government". See Giandomenico Majone, "The Credibility Crisis of Community Regulation”, (2000) 2 Journal of Common Market Studies, 273.

${ }^{2}$ See Damien Geradin, "Institutional Aspects of EU Regulatory Reforms in the Telecommunications Sector: An Analysis of the Role of National Regulatory Authorities", (2000) 1 Journal of Network Industries, 5 . Some agencies have also been spontaneously created by MS to deal with new problems, such as, for instance, food security and doping control.

${ }^{3}$ See Proposal for a Regulation of the European Parliament and of the Council Establishing the European Network and Information Security Agency (the "NISA"), COM(2003) 63 final of 11 February 2003; See also Proposal for the creation of a Community Fisheries Control Agency (the "CFCA"), Communication from the Commission, Towards uniform and effective implementation of the Common Fisheries Policy, $\operatorname{COM}(2003) 130$ final of 21 March 2003; See finally, the proposal for the creation of a European Chemical Agency (the "ECA"), in Proposal for a Regulation concerning the Registration, Evaluation, Authorisation and Restriction of Chemicals establishing a European Chemicals Agency and amending Directive 1999/45 and Regulation on Persistent Organic Pollutants COM(2003) 644 final of 29 October 2003.

${ }^{4}$ See Giandomenico Majone, "The Agency Model : The Growth of Regulation and Regulatory Institutions in the European Union", (1997) 3 European Institute of Public Administration, Maastricht, 9; Edoardo Chiti, "The Emergence of a Community Administration: The Case of European Agencies", (2000) 37 Common Market Law Review, 309; Michelle Everson, "Independent Agencies: Hierarchy Beaters?", (1995) 2 European Law Journal, 180; Richard .H. Lauwaars, "Auxiliary Organs and Agencies in the E.E.C",
} 
originality of this paper will be to examine both NRAs and EAs in one and the same piece. Most existing papers tend indeed to focus on either NRAs or on EAs. Very few pieces attempt to discuss these two categories of bodies under the same analytical roof. Some could, of course, argue that examining NRAs and EAs side by side is not helpful because it entails a risk of comparing apple and peers. One could, for instance, argue that EAs usually possess very limited powers (because of the limits placed by the European Court of Justice - the "ECJ" or the "Court"- in Meroni), whereas the NRAs have large discretionary powers under the national legislation implementing the liberalization directives. ${ }^{5}$ One could also say, while EAs are generally entrusted with technical, scientific, or observatory missions, the NRAs are involved in economic regulation. As will be seen below, these distinctions fail to convince and NRAs and EAs probably hold as many common features as significant differences. Moreover, the aim of this paper is not so much to compare NRAs and EAs, but to explore issues of common interest to these two sets of bodies under a common conceptual roof. Indeed, we believe that NRAs and EAs raise a number of important institutional issues, which are either similar, or at least closely connected. ${ }^{6}$

A first issue relates to the question of the optimal level at which regulation should be undertaken. Although this is a very serious issue in all federal and quasi-federal systems, the EC institutions have failed to give serious thought to this basic question. ${ }^{7}$ For

(1979) 16 Common Market Law Review, 365; Loic Grard, "Sécurité et transport dans l’Union Européenne Le recours aux agences de regulation," (2003) Revue Europe, 4; Ellen Vos, "Reforming the European Commission: What Role to Play for the European Agencies", (2000) 37 Common Market Law Review, 1113; Koen Lenaerts, "Regulating the Regulatory Process: 'Delegation of Powers' in the European Community", (1993) 18 European Law Review, 24; Xenophon A. Yataganas, "Delegation of Regulatory Authority in the European Union - The relevance of the American Model of Independent Agencies", (2001) Jean Monnet Working Paper 3/01; Paul Craig, "The Constitutionalization of Community Administration", (2003) Jean Monnet Working Paper 3/03; Giandomenico Majone, "The New European Agencies: Regulation by Information”, (1997) 4 Journal of European Public Policy, 262; Giandomenico Majone and Michelle Everson, "Institutional Reform: Independent Agencies, Oversight, Coordination, and Procedural Control", (2001) in Olivier De Schutter and al., Governance in the EU; Philipp Steinberg, "Agencies, CoRegulation and Comitology - And What About Politics?" in Christian Joerges, Yves Mény and Joseph H.H. Weiler, "Mountain or Molehill? A Critical Appraisal of the Commission's White Paper on Governance", (2001) Jean Monnet Working Paper 6/01; Renaud Dehousse, "Misfits: EU Law and the Transformation of European Governance", (2002) Jean Monnet Working Paper 2/02. There is less literature on NRAs. See, for instance, Phedon Nicolaides, Arjan Geveke and Anne-Mieke den Teuling, Improving Policy Implementation in an Enlarged European Union - The Case of National Regulatory Authorities, (2003) European Institute of Public Administration; Anastasia K. Verra, "The Question of the National Regulatory Authorities' Independence in the Telecommunications Sector", (2001) 12 European Business Law Review, 175.

${ }^{5}$ The Meroni ruling places restrictive conditions on the delegation of powers to agencies. The case will be analyzed below. See infra text accompanying notes 54-66.

${ }^{6} \mathrm{M}$. Everson considers that both NRAs and EAs share the same goal of facilitating decision-making and that the two groups of agencies are therefore similarly concerned with effective government. Therefore, both categories of agencies raise a number of similar institutional and procedural issues. See M. Everson, supra note 4 at p.185.

${ }^{7}$ This question is closely connected to the principle of subsidiarity. There has been a considerable amount of literature on the implications of subsidiarity in the EC. See Grainne de Búrca, "The Principle of Subsidiarity and the Court of Justice as an Institutional Actor", (1998) 38 Journal of Common Market Studies, 214; George Berman, "Taking Subsidiarity Seriously", (1994) 94 Columbia Law Review, 332; Akos G. Toth, "Is Subsidiarity Justiciable?", (1994) 19 European Law Review, 278; Nicholas Emiliou, 
instance, it is difficult to understand why the Commission has proposed to create EAs in the fields of air and rail transport, whereas it did not consider it necessary to set up EAs in the fields of telecommunications and energy, which are typically ridden by externalities. ${ }^{8}$ We will see below that this incomplete "Europeanisation" of agencies in the field of network industries cannot resist any serious discussion. On the other hand, the opportunity to create EAs in a series of other sectors appears very doubtful. In fact, the decision to grant regulatory duties to EC-wide regulatory agencies or to NRAs has often been based on ad-hoc political considerations rather than on any coherent reflection. This first issue shows the benefits of examining NRAs and EAs under the same roof. Indeed, if a matter has been wrongly deferred to the Member States (hereafter, the "MS") because it has many EC-wide aspects, then the solution must be to create an EA and vice versa. To add some clarity to the debate, we will argue that the questions regarding the level of powers at which regulatory institutions should be taken are to be addressed through the set of tools provided by the economic analysis, and more specifically the economics of federalism. ${ }^{9}$ Reliance on such tools is no stranger to EC law, as the Edinburgh European Council of December 1992 used them as its main source for defining the criteria that should be relied upon when carrying out a test of subsidiarity. ${ }^{10}$

A second issue is whether EC institutions should opt for a more harmonized framework with respect to the institutional aspects of such agencies. There is indeed a great deal of diversity in the ways in which NRAs and EAs are organized. ${ }^{11}$ While diversity brings benefits, it may also involve costs as a highly diversified system may lead to incoherence, complexity and opacity. Generally, the co-existence of a disparate set of NRAs does not help market players operating in different MS as they will have to familiarize themselves with a range of bodies whose structure, competences, procedures and powers vary widely. ${ }^{12}$ Information costs thus explode. Similarly, the creation by EC institutions of a series of uncoordinated, ad-hoc agencies contributes to the view that EC institutions are complex and impenetrable. As the centralization vs. decentralization debate outlined

\footnotetext{
"Subsidiarity: An Effective Barrier Against the 'Enterprises of Ambition'?", (1992) 17 European Law Review, 383; Deborah Cass, "The word that saves Maastricht? The principle of Subsidiarity and the Division of Powers within the European Community", (1992) 29 Common Market Law Review, 1112; Vlad Constantinesco, "Who's Afraid of Subsidiarity?", (1991) 11 Yearbook of European Law, 33.

${ }^{8}$ There is an externality when the action of an economic entity has an impact on another economic actor. An externality is negative when the impact is adverse. For instance, to keep costs down a firm may be tempted to dump the pollutants resulting from the manufacturing process into a river. This is, in turn, costly for society as a whole. Similarly, the decisions (e.g. through legislation) taken by a State may have an adverse impact on other States. This is, for instance, the case when a State lays down lax standards of environmental protection.

${ }^{9}$ On the use of these tools to determine the level at which regulatory intervention should take place in the EC, see Roger Van den Bergh, "The Subsidiarity Principle in European Community Law: Some Insights from Law and Economics", (1994) 1 Maastricht Journal or European and Comparative Law, 337; Roger Van den Bergh, "Subsidiarity as an Economic Demarcation Principle and the Emergence of European Private Law", (1998) 2 Maastricht Journal of European and Comparative Law, 129.

${ }^{10}$ See European Council, Edinburgh, 11-12 December 1992, Conclusions of the Presidency, Part A, Annex 1 at p. 20 .

${ }^{11}$ On the EAs, see M. Everson supra note 4 at p.185. On the NRAs, see D. Geradin supra note 2 at p. 21.

${ }^{12}$ Operators engaged in trans-European activities may face important transaction and search costs. This has been, for instance, experienced by operators in the mobile telecommunications sector when third generation telephony licences were allocated by MS pursuant to distinct procedures. See infra at note 45 .
} 
above, the homogeneity vs. heterogeneity issue is classic economic law issue that gains to be studied at both EC and national levels under a common conceptual framework. ${ }^{13}$

A third and final issue is whether the design of such agencies meets the emerging principles of good governance, which can be found in a variety of national and international instruments. ${ }^{14}$ Good governance is increasingly seen as a key determinant of the success or failure of regulatory bodies. Again, contradictors may argue that governance issues are different at MS level and at EC level because the institutional structure is different (parliamentary regimes in the MS and a non-parliamentary regime in the EC). ${ }^{15}$ However, the "special" or "unique" structure of the EC should not serve as an excuse for poor governance, which often translates into bad management, loss of credibility and inability to achieve results. It is thus no accident that in recent policy documents, the Commission insists on the importance of good governance principles, including independence, accountability, transparency, and participation. ${ }^{16}$ Yet, in practice, it does not do enough to ensure that these principles are complied with by the NRAs created under the impulsion of EC law, as well as by the EAs.

The tone of this introduction may sound harsh and it is perhaps unfair to be too critical of the way EC institutions have approached the issues described above. First, the creation of agencies, either at the EC level or the national level under the impulsion of EC law, has often led to serious improvements in regulatory decision-making. ${ }^{17}$ Moreover, while it has failed to reflect on the problem of regulatory agencies for a long period of time, the Commission is now engaged in a serious process of reflection on the concept of EAs. For instance, the Commission has recently adopted a Communication on "the Operating Framework for the European Regulatory Agencies". ${ }^{18}$ More generally, the Commission has initiated a vast consultation process on the future of governance in the EC. ${ }^{19} \mathrm{We}$

\footnotetext{
${ }^{13}$ See infra at 2.2 .

${ }^{14}$ As far as the international instruments are concerned, a variety of documents have been issued by the OECD. See, for instance, "Best Practice Guidelines for Contracting out Government Services", OECD, 14 February 1997; "Best Practice Guidelines for Evaluation”, OECD, 14 May 1998. The World Bank is also involved in the promotion of good governance standards. The World Bank has, inter alia, developed governance indicators. See "Governance Matters III: Governance Indicators for 1996-2002", Daniel Kaufmann, Aart Kraay and Massimo Mastruzzi, The World Bank, 30 June 2003. Finally, a number of other international institutions such as the United Nations Program for Development are working on these issues.

15 See, on these differences, Stefan Kadelbach, "European Administrative Law and the Law of a Europeanized Administration" in Renaud Dehousse and Christian Joerges (eds.), Good Governance in Europe's Integrated Market, (2002) Oxford University Press.

${ }^{16}$ See White Paper on European Governance, 25 July 2001, COM(2001) 428 final.

${ }^{17}$ A number of authors consider that the development of agencies contributed to improve the effectiveness and credibility of the European regulatory policies. See R. Dehousse, G. Majone and E. Vos, supra note 4.

${ }^{18}$ See Communication from the Commission on the Operating Framework for the European Regulatory Agencies of 11 December 2002, COM(2002) 718 final. An analysis of this Communication is provided below at section 2.2.3.

19 The fraud and mismanagement scandals within the Santer Commission have given rise to the sentiment that the administrative structure of the EU needs strong improvements in terms of accountability and transparency. Thus, the Commission initiated a wide consultation on governance in the EC which led to the adoption of a White Paper on European Governance, supra note 16. Subsequently, the European Commission committed itself to implementing a series of actions in order to implement the improvements proposed in the White Paper. This has led to the adoption of a series of Communications and Guidelines on
} 
believe, however, that these various communications do not satisfactorily address some of the issues described above. In this context, we hope that this article will contribute to the current debate on the status of regulatory agencies in the EC.

Following this introduction, Part II provides an analysis of the NRAs. Part III reviews the EAs. Part IV contains a brief conclusion. For the reasons that have just been explained, we apply a similar analytical framework to NRAs and EAs and both categories are thus examined following an analogous three steps approach. A first step describes the processes which led to the formation of agencies. A second step is the review of three institutional regulatory parameters that have been evoked above, i.e. the level chosen for the creation of an agency, the degree of homogeneity among agencies and the compliance with principles of good governance. A third and final step consists in the formulation of proposals for fine tuning these institutional regulatory parameters.

\section{The National Regulatory Authorities (NRAs)}

The creation of NRAs received a considerable boost with the adoption of EC instruments aimed at liberalizing markets in the field of "network industries" (1). But the creation of such agencies has not necessarily been a smooth process and the decentralized regulatory systems established by the liberalization directives can be subject to criticism. Three institutional regulatory parameters (i.e. level of powers, homogeneity and compliance with principles of good governance) will be analyzed hereafter to provide a comprehensive picture of the NRAs and outline the strength and weaknesses of the existing model (2). The scope for improvements of these parameters will then be explored (3).

1. The development of regulatory agencies at the national level

The development of regulatory institutions at the national level is not a new phenomenon. ${ }^{20}$ Several MS have relied for a long time on regulatory agencies to carry out certain governmental functions. ${ }^{21}$ Two main reasons have traditionally been advanced to justify the creation of such agencies. First, it was thought that some regulatory matters

\footnotetext{
diverse matters. See, for instance, Communication from the Commission, "European Governance: Better Law Making", 5 June 2002, COM(2002) 275 final; Communication from the Commission on Impact Assessment, $\operatorname{COM(2002)~} 276$ final, 5 June 2002; Communication from the Commission, "Towards a reinforced culture of consultation and dialogue - General principles and minimum standards for consultation of interested parties by the Commission", COM(2002) 704 final, 11 December 2002. There is a wide body of literature on the concept of governance in the EC. See, for instance, Joanne Scott, David. M. Trubek and Andrea Lenschow, "Law and New Approaches to Governance in Europe", (2002) 8 European Law Review, 1; Philip Allott, "European Governance and the Re-Branding of Democracy", (2002) 1 European Law Review, 60; Daniel Wincott, "Looking Forward or Harking Back?: The Commission and the Reform of Governance in the European Union”, (2001) 5 Journal of Common Market Studies, 897.

${ }^{20}$ See M. Everson, supra note 4, at p.182. See Tony Prosser, Law and the Regulator, (1997) Clarendon Press Oxford, at p. 1 and the Public Report of the French Council of State, Les autorités administratives indépendantes, (2001) Etudes et Documents du Conseil d’Etat, n52 at pp.281-284.

${ }^{21}$ See T. Prosser, supra note 20. Especially the detailed description of the various regulatory institutions that have been set up in the UK since the late nineteenth century, at pp.35-51; See also Anthony Ogus, Regulation: Legal Form and Economic Theory, (1994) Clarendon Press Oxford.
} 
(e.g., the regulation of money supply or the media) should be removed from politicians (who might be tempted to base regulatory decisions on short-term electoral goals) and placed in the hands of independent regulators. ${ }^{22}$ Second, it was also believed that some regulatory issues were so complex and specialized that they should be handled by a body of experts. ${ }^{23}$

In this respect, many examples of regulatory agencies can be found in the MS. In France, for instance, the first regulatory authorities date back from the period following the second world-war with the creation of 5 authorities in about two decades. The number of agencies has subsequently grown over the years and, in a report published in 2001, the French Council of State identified 34 "Independent Administrative Authorities" (hereafter, "IAAs"). ${ }^{24}$ These agencies have been established in order to regulate a wide range of activities, including the protection of civil liberties and the press, the regulation of banks and financial markets, the protection of competition and the prevention and fight against doping in sport. ${ }^{25}$

However, a major factor of growth in the creation of NRAs was the process of liberalization of State monopolies, which was engaged by the Commission in the late $1990 \mathrm{~s}$ in the area of network industries. ${ }^{26}$ This new process required not only the removal of special or exclusive rights, but also the adoption of a set of rules designed to facilitate the arrival of competition in contestable market segments, as well as to regulate remaining natural monopolies. ${ }^{27}$ The implementation and enforcement of such rules could not be entrusted to the incumbents since these companies would remain players in the market once it is open to competition. ${ }^{28}$ In addition, in countries where the government retains ownership rights on the incumbent, regulatory tasks could not be entrusted to it as this would create an obvious conflict of interest. ${ }^{29}$ Independent mechanisms of regulation had thus to be provided for. Meanwhile, the choice of legislating through directives led to the consequence that MS were left free to choose the designs of such mechanisms. ${ }^{30}$

\footnotetext{
${ }^{22}$ See Warrick Smith, "Utility Regulators - The Independence Debate”, (October 1997) 127 Viewpoint 1, Public Policy for the Private Sector, The World Bank.

${ }^{23}$ See, on this, R. Dehousse, supra note 4.

${ }^{24}$ See Report of the French Council of State, supra note 20 at p.306.

${ }^{25}$ Id. at pp.300-306.

${ }^{26}$ See D. Geradin, supra note 2; See also, Françoise Blum, "The Recent Case-law of the European Court of Justice on State Monopolies and its Implications for Network Industries”, (2000) 1 Journal of Network Industries, 55.

${ }^{27}$ See D. Geradin, supra note 2. See P. Nicolaides, A. Geveke and A.M. den Teuling, supra note 4 at p.63.

${ }^{28}$ See ECJ, 13 December 1991, RTT vs. GB-Inno-BM, C-18/88, ECR 1991, p.I-5491 at §28: “Articles 3(f), 90 and 86 of the EC Treaty preclude a Member State from granting to the undertaking which operates the public telecommunications network the power to lay down standards for telephone equipment and to check that economic operators meet those standards when it is itself competing with those operators on the market for that equipment".

${ }^{29}$ See Article 3(2) of Directive 2002/21 on a common regulatory framework for electronic communications networks and services (hereafter, the "Framework Directive") of 7 March 2002, OJ L 108 of 24 April 2002, pp.33-50: "Member States that retain ownership or control of undertakings providing electronic communications networks and/or services shall ensure effective structural separation of the regulatory function from activities associated with ownership or control."

${ }^{30}$ For a good discussion on the main features of directives, see Paul Craig and Grainne de Búrca, EU Law Text, Cases and Materials, (2003) $3^{\text {rd }}$ Ed., Oxford University Press, p.99. From a legal perspective the
} 
Pursuant to these requirements, most MS decided to set up independent structures taking the form of NRAs. In the telecommunications sector, this took place in the early 1990s, with the creation of regulatory institutions in all of the MS. ${ }^{31}$ In the energy sector, the emergence of these entities dates back from the second half of the 1990s. As will be seen below, the vast majority of the MS have now created energy regulators. ${ }^{32}$ Finally, in the railway sector, agencies are currently being established in most MS as a response to the ongoing liberalization process.

The creation of national regulatory institutions under the impulsion of EC law may not be limited to network industries. Several recent Commission policy documents suggest that, in a variety of sectors, new authorities might be instituted at the national level. In the context of the internal market, for instance, the Commission has recently shown support to the creation of national "watchdogs" for the supervision of the enforcement of internal market legislation. ${ }^{33} \mathrm{~A}$ new wave of NRAs stimulated by EC legislation is thus to be expected in the years to come.

\section{Review of the institutional regulatory parameters}

The creation of NRAs under the impulsion of EC law is still a relatively new phenomenon and both the Commission and the MS are still in a learning phase. There is, however, already sufficient experience to assess the strengths and weaknesses of this decentralized regulatory model. Although the NRAs raise a variety of issues, we have decided to focus on three major institutional issues, which, for the sake of convenience, we refer to as "institutional regulatory parameters". A first parameter is the choice of the national level for the regulation of network industries (2.1). A second parameter is the level of homogeneity that exists among NRAs (2.2). A third parameter is the state of compliance of NRAs with requirements of good governance (2.3).

\subsection{Centralization vs. decentralization}

\footnotetext{
choice of a directive as a legislative instrument implies a division of competences between the EC and the MS. The EC institutions set the legislative goals to be achieved, while the MS are left free as to the form and method of achieving these goals. In the field of network industries, the institutional requirements provided for by first generation directive were particularly limited. The new directives tend to define more precise requirements. See infra text accompanying notes 96-125.

${ }^{31}$ See D. Geradin, supra note 2 at p.5.

32 See first benchmarking report on the implementation of the internal electricity and gas market, Commission Staff Woking Paper of 3 December 2001, SEC (2001) 1957.

${ }^{33}$ See Press Release IP/03/1067 of 22 July 2003. This is part of the goals set out in the Communication from the Commission, "Internal Market Strategy - Priorities 2003-2006", COM(2003) 238 final, In this document, the Commission supports the creation of a range of institutions at the national level, to ensure effective implementation of the internal market rules. It is interesting to note that in the context of the protection of personal data, Article 28 of Directive 95/46 requires that MS set up independent public authorities for the monitoring of its provisions. These authorities shall be entrusted with investigative and intervention powers. They can also initiate legal proceedings in case of infringements to the directive. See Article 28 of Directive 95/46 of 24 October 1995 of the Parliament and the Council on the protection of individuals with regard to the processing of personal data and on the free movement of such data, OJ L 281 of 23 November 1995, pp.31-50.
} 
As we have seen, EC law provides for the creation of agencies at both national and EC levels. Although in theory a NRA and an EA could deal with similar matters (the former working, for instance, on the basis of the guidelines provided by the latter), there is in practice little overlap between NRAs and EAs. While the NRAs created through the impulse of the liberalization directives only operate in the field of network industries (although we have seen that additional national authorities may be created in the future to address other regulatory issues), EAs deal with a wide range of matters which are not necessarily connected to economic regulation sensu stricto. ${ }^{34}$

The current state of affairs is, however, disturbing. There seems to be a mismatch between the level at which regulatory authority has been allocated and the type of issues that needs to be treated. ${ }^{35}$ This should not come as a surprise as there has never been any comprehensive Commission study on the allocation of regulatory powers in the EC. Of course, this issue was examined a few years ago in the area of telecommunications when Directive 97/33 required the Commission to investigate the added value of the setting up of a "European Regulatory Authority". ${ }^{36}$ To this purpose, the Commission ordered a study, which was based on a dubious methodology relying on surveys among stakeholders, which found that there was not among these enough support for the creation of a European Regulatory Authority. ${ }^{37}$ In its so-called "1999 Review", the Commission

\footnotetext{
${ }^{34}$ See infra Part III.

35 This mismatch was recently acknowledged in a high-profile study (generally referred to as "the Sapir Report") delivered by a group of distinguished scholars to the Commission. The report pointed out that "a policy may be inappropriately allocated between the EU and the MS levels with respect to the objective that is being pursued (either inappropriate centralisation or decentralisation)" and consequently raised the question whether "the current assignment of competences between the EC and the MS could be considered optimal". See "An Agenda For a Growing Europe - Making the EU Economic System Deliver", Report of an Independent High-Level Study Group established on the initiative of the President of the European Commission, July 2003, at p.88. This document is available at www.europa.eu.int/comm/dgs/policy advisers/experts group/ps2/odcs/agenda en.pdf

${ }^{36}$ Pursuant to Article 22 of Directive 97/33, the Commission shall address a report to the European Parliament on the review of the directive and, shall also investigate in the added value of the setting up of a European Regulatory Authority to carry out those tasks which would prove to be better undertaken at Community level. This provision was adopted following the pressures by the European Parliament on the Council of ministers. See Directive 97/33 of the European Parliament and of the Council of 30 June 1997 on interconnection in Telecommunications with regard to ensuring universal service and interoperability through application of the principles of Open Network Provision (ONP), OJ L 199 of 26 July 1997, pp.3252; See Giandomenico Majone, "Convergence dans les approches nationales - Innovations politiques et retards institutionnels" in La regulation des services publics en Europe, (1998) TEPSA at p.371.

37 See Final Report on the study "The possible added value of a European Regulatory Authority for telecommunications", prepared by Eurostrategies/Cullen International for the Commission, in response to a request from the EP, 22 December 1999 at pp.209-218 and in particular: "We have critically reviewed the various options. The case for a radical departure in setting up a 'hard' independent EU regulator has not been made out [...]. The overall results indicate a significant level of support for EU involvement for issues that are closely related to competition and to the establishment of a Pan-European telecommunications market. For other regulatory topics, the support for EU involvement is less convincing and even where the support for EU involvement is high, there is not support for the having a 'European Regulatory Authority'. Only in the case of competition matters (where the Competition Directorate General already exists as a European Regulatory Authority) is there a majority in favour of such a solution". See also the following reports: Report made by NERA \& Denton Hall, March 1997, "Issues associated with the creation of a European Regulatory Authority for telecommunications"; Report by Forrester, Norall and Sutton, 1995,
} 
then concluded that such an authority would not bring sufficient added value to justify the costs. $^{38}$

Perhaps, the most effective way to address issues regarding the level for the allocation of powers is to rely on the tools offered by economic analysis. Scholars specialized in the economics of federalism generally argue that there are two main types of circumstances where centralized intervention is desirable. ${ }^{39}$

The first relates to the presence of externalities. ${ }^{40}$ Legislators and regulators generally fail to bear sufficient attention to the impact of their legislative/regulatory decisions outside their jurisdictions (hence, the term "externalities"). Where the presence of externalities is to be expected, it is thus preferable to entrust regulatory-making at a higher level of power. It seems that many decisions taken by NRAs are likely to create externalities, either because the matter to be dealt with is in its very essence of a cross-border nature (e.g. the regulation of cross-border regulatory exchanges) or because the decision to be taken will affect the competitiveness of market players and can thus impact the conditions of competition in the internal market (e.g. the adoption of interconnection rates in telecommunications). ${ }^{41}$ In both sets of circumstances, there is obviously much to be gained by having decisions taken at the EC level.

The second argument in favour of centralization relates to the presence of economies of scale and transaction costs savings. ${ }^{42}$ Economic theory teaches that if economies of scale are important, a single supplier may be more efficient than several competing suppliers. ${ }^{43}$ When regulatory economies of scale are present, centralized standard-setting and enforcement procedures may thus be more efficient than decentralized action. In technically complicated or analysis-intensive regulatory fields (such as network pricing, capacity allocation etc.), economies of scale can be realized by entrusting regulatory duties to a centralized authority even if the implementation is carried out at the national level to ensure that concrete decisions take into account local circumstances. Similarly,

"The Institutional framework for the regulation of Telecommunications and the application of EC Competition rules".

${ }^{38}$ See Communication from the Commission, Towards a new framework for Electronic Communications infrastructure and associated services - The 1999 Review, COM(1999) 539 final at p.9.

39 See Daniel C. Esty and Damien Geradin, "Regulatory Co-opetition" in D. Esty and D. Geradin, Eds, Regulatory Competition and Economic Integration - Comparative Perspectives, (2001) Oxford University Press.

${ }^{40}$ See R. Van den Bergh, "The Subsidiarity Principle in European Community Law: Some Insights from Law and Economics", supra note 9 at p.343.

${ }^{41}$ This has been acknowledged in the Green Paper on Services of General Interest, COM(2003) 270 final of 21 May 2003, Annex at $§ 53$. This is, for instance, the case of cross-border exchanges of electricity. An EC regulation has recently been adopted to deal with the issue of cross border electricity flows, i.e. the physical flows of electricity on a transmission network of a MS that results from the impact of the activity of producers and/or consumers outside that MS on its transmission network. See infra note 77.

${ }^{42}$ See R. Van den Bergh, "The Subsidiarity Principle in European Community Law: Some Insights from Law and Economics", supra note 9 at p.343.

${ }^{43}$ Economic activities where large economies of scale can be achieved (e.g., electricity transmission) are generally considered "natural monopolies". See William Sharkey, The Theory of Natural Monopoly, (1982) Cambridge University Press. Similarly, areas where regulatory economies of scale can be achieved may be considered "natural legal monopolies". 
centralization and uniformity can, under certain circumstances, reduce transaction costs. In an integrated market, inconsistent procedures regarding authorizations, allocation of scarce resources, and a range of other regulatory matters may create barriers to trade. ${ }^{44}$

Although this would require a detailed analysis, which would go beyond the scope of this article, there is a strong case in favour of centralization of regulatory decisions. ${ }^{45}$ It is true that the Commission is already assuming some regulatory duties. Yet, it is not clear that the Commission is well placed to undertake these tasks as it might not necessarily have the expertise and the independence (e.g. the insulation from political and industry pressures) to act as a regulator. It is thus subject to question why so little consideration has been given to the creation of regulatory agencies at the EC level.

In fact, the creation of European regulatory agencies in the above sectors raised political and legal problems. With regards to political aspects, the creation of EC agencies (this is particularly true in the field of network industries) has been seen by many as a movement towards deeper centralization, as well as a risk of increasing bureaucracy. ${ }^{46} \mathrm{MS}$ have therefore often opposed the creation of European regulatory agencies. ${ }^{47}$ They have generally preferred a system of decentralized regulation on the basis of NRAs in line with the principles of subsidiarity. In the field of network industries, MS pressures for decentralization have probably been even stronger because of the fact that most these industries were, until a few years ago, State controlled. ${ }^{48}$

\footnotetext{
${ }^{44}$ See R. Van den Bergh, "The Subsidiarity Principle in European Community Law: Some Insights from Law and Economics", supra note 9 at p.344.

45 A very good illustration of the two preceding arguments can be found in the spectrum licensing procedures for third generation mobile phones (hereafter, "3G licences") that were implemented at the MS level almost two years ago. See Nicolas Petit, "3G Mobile Communications - Competition Law and Regulatory Developments", to be published in the Journal of Network Industries. On the basis of the subsidiarity principle, EC legislation entrusted MS with the assignment of the $3 \mathrm{G}$ licences. The choice of decentralization led to the apparition of important externalities and an explosion of the transaction costs for operators. See Decision 128/1999 of 14 December 1998 on the co-ordinated introduction of a thirdgeneration mobile and wireless communications system (UMTS) in the Community, OJ L 17 of 22 January 1999, pp.1-7. As far as externalities are concerned, the "first movers" MS, (i.e. those that were the first to allocate $3 \mathrm{G}$ licences) received considerable amounts of money for the licences. This created a negative externality towards the MS that decided to allocate licences later as most mobile operators that had cashed out very important sums in the first MS were financially unable to apply for $3 \mathrm{G}$ licences in other MS. The allocation of licences in these MS led to considerably lesser fees and, in some countries, a number of licences were left unallocated. In addition to this, the decentralized approach to licensing raised transaction costs, in particular for those operators that were willing to implement a pan-European strategy. See Laura Pontiggia and Ann Vandenbroucke, "The Impact on Competition of Differences in Telecommunications Licensing Regimes", (2000) 38 Communications \& Strategies, 41. In a situation of this kind, there is thus a strong case for the centralization of licensing procedures.

${ }^{46}$ See P. Steinberg supra note 4 at pp.16-17.

47 See, for instance, in the field of financial regulation Yannis V. Avgerinos, "EU Financial Market Supervision Revisited: The European Securities Regulator", (2003) Jean Monnet Working Paper 6/03 at p.62-63. See also Robert Baldwin and Martin Cave, Understanding Regulation - Theory, Strategy and Practice, (1999) Oxford University Press, at p.166.

${ }^{48}$ See D. Geradin, supra note 2.
} 
In addition to this, it seems that some institutions have feared a taking away of their powers and the apparition of rival entities. ${ }^{49}$ This is especially true in fields where EC institutions hold important powers. In this respect, the opposition of the Commission to the creation of an EC Competition Agency (or a European Cartel Office) is worth recalling. ${ }^{50}$ More generally, in the White Paper on European Governance, the Commission favours a rather restrictive interpretation of the Meroni doctrine, which provides the conditions for setting up agencies at the EC level. ${ }^{51}$ This is all the more curious when we know that the Commission is traditionally in the "avant garde" in terms of promoting dynamic Treaty interpretations. For instance, the Commission has promoted very ambitious interpretations of Article 86 of the EC Treaty or of the concept of "collective dominance" under the EC Merger Regulation. ${ }^{52}$ Obviously, the Commission promotes dynamic Treaty interpretations when such interpretations might result in an extension of its own competences. On the other hand, the Commission seems to favour more restrictive interpretations when its competences may be reduced. ${ }^{53}$

But is Meroni a real obstacle or a simple excuse used by the Commission to retain its regulatory influence in several important sectors? Let's try to clarify this matter. As a starting point, it is important to note that the EC Treaty does not explicitly provide for the formation of regulatory agencies, nor does it set out a special procedure to this end. Agencies are therefore instituted on the basis of the classic legislative procedures provided by the EC Treaty. Thus, agencies emerge thanks to the intervention of other EC institutions. The recourse to the creation of such entities is, however, subject to limitations. In the landmark Meroni case, the ECJ clarified the conditions under which a delegation of powers could be granted to a new entity. ${ }^{54}$ Pursuant to this judgment, institutions cannot "confer upon the authority, powers different from those which the delegating authority itself received under the Treaty". ${ }^{55}$ In other words, EC institutions cannot entrust agencies with powers they do not themselves enjoy. Furthermore, the Court held that, for a delegation of powers to be compatible with the Treaty, it had to

\footnotetext{
${ }^{49}$ We mean the Council and the Commission. See P. Steinberg supra note 4 at p.14. Also, several committees that are currently involved in technical matters may be hostile to the transfer of such matters to other entities. In addition, it will be noted that the EP has favoured, a strict interpretation of the Meroni doctrine. See Resolution of the European Parliament, A3-0414/92 of 19 January 1993, OJ C 42 of 15 February 1993 at p.63.

50 See Karel Van Miert, "The Proposal for a European Competition Agency", (Summer 1996) EC Competition Policy Newsletter, 1; Claus-Dieter Ehlermann, "Reflections on a European Cartel Office", (1995) 471 Common Market Law Review, 479; Alan J. Riley, "The European Cartel Office: A Guardian Without Weapons?", (1997) 1 European Competition Law Review, 3. Interestingly, the Sapir report has supported the creation of an independent European competition agency. See supra note 35.

51 According to Steinberg the Commission's interpretation of the Meroni doctrine in the White Paper is rather restrictive: "the very careful approach of the White Paper towards agencies in general and regulatory agencies in particular, clearly reflects the Commission's reticence with regards to the establishment of further agencies. This reflects the Meroni doctrine." See P. Steinberg, supra note 4 at p.14.

${ }^{52}$ Let us recall the extremely wide interpretation of the concept of collective dominance in the Airtours decision. See Commission Decision of 22 September 1999, Airtours / First Choice, IV/M.1524, OJ C 124 of 5 May 1999.

53 This is in line with the finding by Majone that the Commission adopts a reluctant approach towards measures which would result in a loss of powers. See G. Majone, supra note 1 at p.286.

${ }^{54}$ See ECJ, 13 June 1958, Meroni vs. High Authority, 9/56, ECR 1957/1958, p.133.

${ }^{55}$ Id. at $\$ 40$.
} 
involve only "clearly defined executive powers the exercise of which can, therefore, be subject to strict review in the light of criteria determined by the delegating authority". ${ }^{56}$ By contrast, the possibility of delegating wide discretionary powers was explicitly dismissed by the ECJ on the basis of Article 7 of the EC Treaty. This provision embodies the so-called principle of "institutional balance". According to the Court, this principle could be rendered ineffective in cases of delegations of wide discretionary powers. ${ }^{57}$ The application of this case law to the liberalized sectors restricts the possibility of instituting EC-wide agencies enjoying legislative, executive and quasi-judicial powers. Indeed, regulation in these fields requires complex evaluations, the exercise of a margin of appreciation, as well as the possibility to adopt quasi-legislative norms so as to clarify the regulatory framework in which operators intervene.

We consider, however, that the implications of the Meroni doctrine should not be exaggerated. Indeed, this doctrine was elaborated upon in the particular context of the European Coal and Steel Community where the High Authority had been endowed with wide implementation and regulatory powers deriving from the Treaty. ${ }^{58}$ In the EC context, situations of this kind are rare as in principle implementation powers lie with national administrations. ${ }^{59}$ The granting of implementation powers to agencies would therefore not amount to a delegation of power from an EC institution to a regulatory authority but rather to the extraction of powers from the national administrations. ${ }^{60}$ In addition, taking note of the US practice, it has been suggested that the delegation doctrine could be reconciled with the institutional balance principle. ${ }^{61}$ Since delegation lightens the EC Institutions workload, it may improve the quality of the decision-making process. The transfer of technical issues to experts may thus improve the institutions' capability to respect their original Treaty mandate and allow them to focus on their traditional tasks. The institutional balance would thus be well respected and eventually improved with delegation. ${ }^{62}$ In addition, it is to be recalled that, in other contexts, the institutional balance principle has been interpreted very dynamically. In Les Verts the ECJ held that,

\footnotetext{
${ }^{56}$ Id. at $\$ 44$.

${ }^{57}$ The ruling in Meroni was confirmed in Romano, where the European Court of Justice held that "a body such as the administrative commission may not be empowered by the Council to adopt act having the force of law". However, the latter case can be distinguished from the former since the Court did not explicitly rely on the "institutional balance" principle but on Article 211 of the EC Treaty, which states the missions of the Commission. See ECJ, 14 May 1981, Giuseppe Romano vs. Institut national d'assurance maladieinvalidité, 98/80, ECR 1981, p.1241

${ }^{58}$ See R. Dehousse, supra note 4 at p.12.

${ }^{59} \mathrm{Id}$.

${ }^{60}$ Such idea is formulated by several commentators. See R. Dehousse, supra note 4 at p.12 and M. Everson, supra note 4 at p. 10. See also X. Yataganas, supra note 4 at p.40, speaking of an "Europeanization of powers".

${ }^{61}$ See the explanations provided by M. Everson on the US Supreme Court interpretation of the principle of "balance of powers", supra note 4 at p. 190.

${ }^{62}$ In the US, where the constitutional principle of separation of powers is firmly established, the US Supreme Court has nonetheless adopted a dynamic interpretation of the "balance of powers". The Court did not take the principle at face value. Instead of opting for a literal and restrictive interpretation of it, the Court rather considered that enhanced efficiency in decision-making was improving the balance of powers. On the case law of the US Supreme Court see X. Yataganas, supra note 4 at pp.16-17. See M. Everson, supra note 4 at p.6, who considers that, ironically, in the US the "balance of powers" principle has been used to strengthen the agencies.
} 
contrary to the wording of the EC Treaty, the acts taken by the European Parliament (hereafter, the "EP") could be challenged on the basis of Article 230 of the same Treaty. ${ }^{63}$ In Parliament vs. Council, the Court decided that the principle of institutional balance implied the possibility for the EP to initiate annulment proceedings pursuant to Article $230{ }^{64}$ Finally, the Meroni doctrine leads to a growing complexity of the regulatory structures in liberalized industries, which is not good for economic operators and consumers. ${ }^{65}$ Several proposals for overcoming the obstacle raised by Meroni will be formulated below. ${ }^{66}$

Instead of the more centralized approach we recommend, the Commission has opted for a model of "managed decentralization" whereby NRAs are entrusted with important regulatory powers with, however, a certain degree of supervision by the Commission. The new Framework Directive on electronic communications strengthens the powers of the NRAs, which will be ultimately responsible for defining markets and identifying the operator significant market power to which the heavier regulatory obligations contained in the specific directives will apply ${ }^{67}$ In exchange for the increased discretionary powers granted to NRAs, the directive provides for a cooperation mechanism whereby whenever a NRA intends to take a specific measure in a field where it is granted a certain margin of appreciation (definition of the market, analysis of the market, etc.), and whenever this measure is liable to affect trade between MS, it has to inform the Commission and the other NRAs. ${ }^{68}$ The Commission as well as the other NRAs may then make comments to the relevant NRA concerned within a certain period of time. ${ }^{69}$ The NRA has to take the utmost account of these comments when adopting its measure. In some cases, the Commission can even force the NRA to withdraw its draft measure. ${ }^{70}$ In addition, cooperation between authorities has been further institutionalized with the setting up of formal network. A Commission's decision of July 2002 established a European Regulators Group for Electronic Communications Networks and Services with a view to ensure the consistent application of the regulatory framework. ${ }^{71}$

This last aspect of the directive is interesting as it provides a good illustration of a new pattern in EC law, which is to give national agencies greater discretionary powers, but to combine this form of decentralization with cooperation mechanisms designed to create a partnership among the national agencies, but also between the national agencies and the Commission. This "networking" approach is, for instance, at the core of the new Regulation 1/2003 which, in the field of competition law, transfers substantial powers to

${ }^{63}$ ECJ, 23 April 1986, Les Verts vs. Parliament, 294/83, ECR 1986, p.1339.

${ }^{64}$ ECJ, 22 May 1990, Parliament vs. Council, 70/88, ECR 1990, p.I-2041.

${ }^{65}$ See D. Geradin, supra note 2 at p. 25.

${ }^{66}$ See infra at 3.1.

${ }^{67}$ See Article 14, 15 and 16 of the Framework Directive, supra note 29.

${ }^{68}$ Id. at Article 7(2).

${ }^{69}$ Id. at Article 7(3).

${ }^{70} \mathrm{Id}$. at Article 7(4) at b.

${ }^{71}$ See Commission Decision of 29 July 2002, establishing the European Regulators Group for Electronic Communications Networks and Services, OJ L 200 of 30 July 2002, pp.38-40. Recently, a similar network has been established in the electricity and gas sectors, see Commission Decision of 11 November 2003 on establishing the European Regulatory Group for Electricity and Gas, OJ L 296 of 14 November 2003, pp.34-35. 
the National Competition Authorities (hereafter, the "NCAs"), but combines this transfer with cooperation mechanisms among NCAs, as well as between the NCAs and the Commission. $^{72}$ In substance, a number of reciprocal consultation and information mechanisms between the NCAs and the Commission are set up. NCAs are, for instance, required to inform the Commission when they investigate a case or adopt a formal decision. ${ }^{73}$ These mechanisms may, however, prove unnecessarily time-consuming and costly since the rules governing cooperation between agencies are complex and do not eradicate the possibility of conflicts of competence. ${ }^{74}$ To mitigate these risks in the field of competition law, the Commission is currently proposing the adoption of a set of communications that detail jurisdictional and procedural rules. ${ }^{75}$

\footnotetext{
${ }^{72}$ See Council Regulation 1/2003 of 16 December 2002 on the implementation of the rules on competition laid down in Articles 81 and 82 of the Treaty, OJ L 1 of 4 January 2003, pp.1-25. There have been numerous comments on the decentralization of the implementation of competition rules and the creation of a network of competition authorities: See Damien Geradin, "Competition Between Rules and Rules of Competition: a Legal and Economic Analysis of the Proposed Modernization of the Enforcement of EC Competition Law", (2002) 1 Columbia Journal of European Law, 1; Hans Gilliams, "Modernisation: from policy to practice", (2003) 28 European Law Review, 451; Jacques Bourgeois and Christophe Humpe, "The Commission's Draft 'New Regulation 17', (2002) 2 European Competition Law Review, 43; Claus-Dieter Ehlermann and Isabela Atanasiu, "The Modernisation of E.C. Antitrust Law: Consequences for the Future Role and Function of the EC Courts", (2002) 2 European Competition Law Review, 72; Tim Jones, "Regulation 17: The Impact of the Current Application of Articles 81 and 82 by National Competition Authorities on the European Commission's Proposals for Reform", (2001) 10 European Competition Law Review, 405; Mario Todino, "Modernisation from the Perspective of National Competition Authorities: Impact of the Reform on Decentralised Application of E.C. Competition Law", (2000) 8 European Competition Law Review, 348; James S. Venit, "Brave new world: The Modernization and decentralization of enforcement under Articles 81 and 82 of the EC Treaty", (2003) 40 Common Market Law Review, 545; Robert Kovar, "Le règlement du Conseil du 16 décembre 2002 relatif à la mise en œuvre des règles de concurrence prévues aux articles 81 et 82 du traité", (2003) 7 Dalloz Chroniques, 478; Laurence Idot, "Premières vues sur le nouveau Règlement de mise en œuvre des articles 81 et 82", February 2003 Revue Europe, 4; Emil Paulis et Céline Gauer, "La réforme des règles d'application des articles 81 et 82 du Traité", (2003) 97 JT Droit Européen, 65. A similar trend, though more limited, is being currently observed in the electricity and gas sectors. See Directive 2003/54 of the European Parliament and of the Council of 26 June 2003 concerning common rules for the internal market in electricity and repealing Directive 96/92, OJ L 176 of 15 July 2003, pp.37-55 and Directive 2003/55 of the European Parliament and of the Council of 26 June 2003 concerning common rules for the internal market in natural gas and repealing Directive 98/30, OJ L 176 of 15 July 2003, pp.57-78.

${ }^{73}$ See Article 11 of Regulation 1/2003, supra note 72. A number of additional cooperation mechanisms are provided for. NCAs have the possibility to ask the Commission's opinion when EC law is at stake. The Commission shall disclose the most relevant documents it has collected to NCAs. NCAs and the Commission can exchange all kinds of information, including confidential ones. For a good description of these mechanisms, see the articles mentioned at note 72 .

${ }^{74}$ See D. Geradin, supra note 72. Furthermore, one can observe a growing recourse to 'committees' superposed to the networks of authorities. In the telecommunications sector, several committees composed of MS representatives have been created. This is the case of the ONP Committee and the Licensing Committee which have been set up in 1998. Under the new regulatory framework a new committee has been created (the Communications Committee, "COCOM") with a view to replace the two former committees. These committees have frequently been criticized on the ground of lack of independence, accountability, transparency. See M. Everson, supra note 4 at p.193 and X. Yataganas, supra note 4 at pp.35-36. In addition, the superposition of various regulatory structures with different procedures and powers leads to an unnecessary complexification of the regulatory framework.

75 See the so-called "Modernisation Package", which completes the reform of the rules implementing Articles 81 and 82 of the EC Treaty and which consists of 9 communications and a Regulation, available at http://europa.eu.int/comm/competition/antitrust/legislation/
} 
Another model, which has been used in the energy sector, is for the Commission to encourage market players to cooperate in order to find solutions to the main cross-border issues through voluntary measures. This led to the creation of the so-called Florence Forum (dealing with cross-border issues in electricity) and the Madrid Forum (dealing with cross-border issues in gas). ${ }^{76}$ The Commission realized, however, the intrinsic limits to this cooperative approach and decided to deal with cross-border issues through EC legislation. $^{77}$ The interesting aspect of this new legislative approach is that the Commission is given quasi-regulatory powers to deal with such cross-border issues. In substance, Regulation 1228/2003 entrusts the Commission with the power to decide on the amounts of compensation payments payable to operators for costs incurred as a result of hosting transit flows of electricity on their networks. ${ }^{78}$ It also entrusts the Commission with the power to adopt and amend guidelines on a variety of issues regarding the intertransmission system operator compensation mechanism. ${ }^{79}$ Thus, instead of proposing the creation of a European Energy Authority, which seemed to be the logical approach, the Commission rather sought to extend its own powers in the energy field.

\subsection{Homogeneity vs. diversity}

The homogeneity/diversity issue is another debate, which has preoccupied law and economics scholars. ${ }^{80}$ Indeed, while some commentators praise the virtue of homogeneity in terms of reduction of transaction costs, trade facilitation, and transparency, others insist on the benefits of diversity which allows different approaches to be explored (hence triggering a process of regulatory experimentation) and the adoption of systems that will match local preferences. As we have seen in the preceding section, the decentralized approach to regulation adopted by the EC institutions naturally tends to promote diversity. Nevertheless, we will examine hereafter the extent of this diversity. We will also discuss whether a greater degree of homogeneity would be desirable.

In general, the procedural approaches adopted by the MS when establishing agencies have followed a very heterogeneous pattern. This may be explained by the recourse to the

\footnotetext{
${ }^{76}$ See, on the "Florence Forum", Burkhard Eberlein, "Regulating cross-border Trade by Soft Law? The Florence Process in Supranational Governance of Electricity Markets", (2003) 2 Journal of Network Industries, 13. Information on the Florence Forum is available at http://www.europa.eu.int/comm/energy/en/elec_single_market/florence/index_en.html. Information on the Madrid Forum is available at http://www.europa.eu.int/comm/energy/en/gas single market/madrid.html.

${ }^{77}$ In March 2001, the Commission issued a Proposal for a regulation on conditions access to the network for cross-border exchanges in electricity $\operatorname{COM}(2001) 125$ final of 13 March 2001. In the proposal, the Commission acknowledged the useful output of the Florence Forum but nevertheless stressed a number of disadvantages that were linked to such form of regulation, in particular with regards to cross-border trade in electricity (i.e. cross-border transmission, tariffs and congestion management on interconnections). See Proposal at p.3. The Proposal has now been adopted. See Regulation 1228/2003 of the European Parliament and of the Council of 26 June 2003 on conditions for access to the network for cross-border exchanges in electricity OJ L 176 of 15 July 2003, pp.1-10. See also the comments in the Green Paper on Services of General Interest, supra note 41 at p.50.

${ }^{78}$ See Article 3(4) of Regulation 1228/2003, supra note 77

${ }^{79}$ See Article 8 of Regulation 1228/2003, supra note 77.

${ }^{80}$ See D. Esty and D. Geradin ("Regulatory Co-opetition"), supra note 39.
} 
"directive" instrument, which leaves considerable room to the MS when choosing the methods of implementation. In the field of network industries, first-generation directives left MS free to shape the institutional structure, as well as the powers and the scope of competence of the NRAs. ${ }^{81}$ As a result, MS have opted for different models based on legal, economic, political, and cultural factors. ${ }^{82}$ For this reason, it is extremely difficult and probably useless to provide a comprehensive typology of the NRAs. It is, however, possible to identify their main features, which emphasize the differences existing among them.

First, there is some heterogeneity with respect to the bodies that have been entrusted with the regulatory duties. In the field of energy, for instance, most countries have created sector-specific agencies. ${ }^{83}$ Other countries entrusted the regulatory duties deriving from EC directives to economy-wide competition authorities rather than to sector-specific authorities. ${ }^{84}$ For instance, in the energy sector (gas and electricity), Germany entrusted its competition authority (the Bundeskartellamt) with the implementation of sectorspecific legislation derived from the EC liberalization directives. ${ }^{85}$ Similarly, in the Netherlands, the Office for Energy Regulation (Dte) was set up as a chamber of the Dutch Competition Authority (Nma). ${ }^{86}$ This approach might, however, change in the future as the new directive, which requires that MS "designate one or more competent bodies with the function of regulatory authorities", also requires that these bodies be competent to fixing or approve tariffs, a task that competition authorities are generally not qualified for. ${ }^{87}$

81 See Commission Directive 90/388 of 28 June 1990 on Competition in the Markets for Telecommunications Services, OJ L 192 of 24 August 1990, pp.10-16; See Directive 96/92 of the European Parliament and of the Council, 19 December 1996 concerning Common Rules for the Internal Market in electricity, OJ L 27 of 30 January 1997, pp.20-29. See Directive 98/30 of the European Parliament and of the Council of 22 June 1998 concerning Common Rules for the Internal Market in Natural Gas, OJ L 245 of 4 September 1998, pp.1-12.

${ }^{82}$ See Green Paper on Services of General Interest, supra note 41, Annex at $§ 53$.

${ }^{83}$ This is the case of Austria (Elektricity Control Austria), Belgium (Commission pour la Régulation de l'Electricité et du Gaz, CREG), Denmark (Danish Energy Regulatory Authority, DERA), Finland (Energy Market Authority, EMY), France (Commission de la Régulation de l'Energie, CRE), Greece (Regulatory Authority of Energy, RAE), Ireland (Commission for Energy Regulation, CER), Italy (Regulatory authority for electricity and gas), Portugal (Energy Services Regulatory Authority, ERSE), Spain (National Energy Commission, CNE), Sweden (Swedish Energy Agency), United Kingdom (Ofgem in Great Britain and Ofreg for Northern Ireland).

${ }^{84}$ Luxemburg has followed neither of these two models and has instead opted for a transversal regulator dealing with all network industries, See the Institut Luxembourgeois de Régulation (ILR), http://www.etat.lu/ILR/content.html

${ }^{85} \mathrm{See}$ http://www.bundeskartellamt.de/english pages.html

${ }^{86} \mathrm{See}$ http://www.dte.nl/en/default.asp

${ }^{87}$ See Article 20 and 23 of Directive 54/2003 of the European Parliament and of the Council of 26 June 2003 concerning common rules for the internal market in electricity and repealing Directive 92/96, OJ L 176 of 15 July 2003, pp.37-56. Such missions are generally beyond the scope of powers entrusted to competition authorities. The new directive thus leads to institutional reforms in some MS such as, for instance, Germany where the Bundeskartellamt does not enjoy the powers mentioned in the directive. The German authorities had to choose among three options (i) strengthening the regulatory powers of the competition authority in the field of energy; (ii) creating a new regulator in the field of energy with such ex ante powers; or (iii) giving regulatory powers over the energy sector to the already existing Telecoms and Postal Regulatory Authority. An official report published on 31 August 2003 supports the latter option, i.e. 
Second, there are important differences among NRAs with respect to the allocation of regulatory powers between the NRAs and other authorities. In the telecommunications sector, for instance, two models emerged for the assignment of regulatory powers. A first category of regulators consists of independent and autonomous agencies exercising the full range of powers including those relating to licensing, interconnection, access, price control, frequency assignment and numbering. This is the case in Austria, Germany, Greece, Ireland, the Netherlands (except for frequencies) and Portugal. A second category of regulators is found in the other MS (Belgium, Denmark, Finland, France, Italy, Luxembourg, Spain, Sweden and the UK) where regulatory powers are shared between the regulator and the relevant Minister. ${ }^{88}$

Third, the scope of industry coverage by the NRAs has also proven to be very heterogeneous. While some MS decided to create a regulatory authority that deals exclusively with telecommunications, other MS opted for an authority that covers either telecommunications and broadcasting or telecommunications and postal services. For instance, in France, the Autorité de Régulation des Télécoms (ART) deals with telecommunications, whereas the Conseil Supérieur de l'Audiovisuel (CSA) is in charge of the audiovisual sector. By contrast, in Italy, Portugal, Spain, Austria, the Autorità per le Garanzie nelle Communicazioni (AGCOM), the Autoridade Nacional de Comunicaçoes (ANACOM), the Comision del Mercado de las Telecommunicaciones (CMT), and the Rundfunk \& Telekom Regulierungs-GmbH (RTR-GmbH) regulate both telecommunications and broadcasting sectors. ${ }^{89}$ In Belgium, The Netherlands, Germany, Greece, Sweden and Portugal, the Institut Belge des Postes et des Télécommunications (IBPT), the Onafhankelijke Telecommunicatie Autoriteit (OPTA), the Regulierungsbehörde für Telekommunikation und Post (Reg TP), the National Telecommunications and Post Commission (EETT) respectively cover both telecommunications and postal services whereas in other MS these sectors are regulated by different bodies. ${ }^{90}$ The case of England is also to be mentioned as it chose to set up a regulator (Ofcom) inspired from the idea of "convergence" as it deals with telecommunications, radio communications, broadcasting and television. ${ }^{91}$

transferring regulation of energy to the RegTP (the German telecommunications regulator). See Enese Lieb-Doczy, "Introducing Energy Sector Regulation in Germany: A Significant Step Forward or the Death Knell for Competition?", 17 September 2003, NERA Economic Consulting.

${ }^{88}$ See Eighth Report from the Commission on the Implementation of the Telecommunications Regulatory Package, "European telecoms regulation and markets 2002", 3 December 2002, COM(2002) 695 final, at p.18.

${ }^{89}$ See the website of ANACOM at http://www.icp.pt, the website of CMT at http://www.cmt.es, the website of AGCOM at http://www.agcom.it, and the website of RTR-GmbH at http://www.tkc.at.

90 See the website of OPTA at http://www.opta.nl, the website of IBPT/BPTI at http://www.ibpte.be, the website of Reg TP at http://www.regtp.de and the website of EETT at http://www.eet.gr.

${ }^{91}$ Ofcom should be operational by the end of 2003. It will be in charge of the duties previously entrusted to the five regulators it will replace, i.e. the Broadcasting Standards Commission, the Independent Television Commission, Oftel, the Radio Authority and the Radiocommunications Agency. See http://www.ofcom.org.uk/ 
As noted above, the main benefit of decentralization is that it has allowed MS to explore a variety of regulatory approaches. ${ }^{92}$ The first ten years of the liberalization process have thus helped policy makers to learn a great deal about institutional strategies in the area of regulation and some of them, such as the UK, have recently decided to opt for a new, improved model of regulation. The relevant question at this stage is whether a greater degree of homogeneity would be desirable. We believe this is the case. Indeed, while diversity holds many virtues, it has also some costs. First, diversity tends to raise transactions costs, and in particular search costs, as companies operating on several markets will have to learn the workings and procedures of various regulatory institutions. In some cases, identifying the relevant authority might be challenge. This type of costs can easily be absorbed by incumbents, which generally enjoy large resources, but may quickly become an obstacle for new, smaller entrants. Second, institutional diversity may also have an impact on the content of regulation and, thus, generate a lack of coherence or even in some cases, distortions of competition, within the single market. It is indeed hard to believe that "converged" regulators, such as Ofcom, will necessarily come up with similar regulatory approaches than regulators whose duties are only limited to one segment of the communications market even if both regulators have to apply the same principles derived from EC law. Arguably, the latter institutional approach (e.g. the maintenance of different regulators for the regulation of telecommunications, audiovisual services, etc.) fails to carry the vision of the new electronic framework for electronic communications.

While more institutional homogeneity may be desirable we believe, however, that a single, harmonized institutional model across MS would be extremely difficult to adopt (given the different legal and administrative tradition and the frustration of the MS's procedural autonomy) and would not necessarily desirable from a policy standpoint. On the other hand, several approaches could be explored to reduce the costs of diversity by bringing some degree of homogeneity, while preserving the benefits of heterogeneity. The first is to rely on soft law instruments, such as guidelines and communications, to encourage the MS to opt for sound institutional practices. International experiences teach that some models are better than others and much could be gained by disseminating best institutional practices through a formal instrument. We will return to this issue below in section 3.2. The second approach consists of maintaining the institutional format chosen by the MS, but to encourage a greater degree of convergence over key principles of governance as these principles have wide implications on the organisation of regulatory agencies. This aspect is examined below.

\subsection{Compliance with the principles of good governance}

\footnotetext{
${ }^{92}$ See D. Geradin, supra note 2 at p.22. The "Regulatory competition" theorists consider that after a period of intense national experimentation, the best institutional practices will "triumph" and spread across jurisdiction. See Joseph McCahery et al (eds.) International Regulatory Competition and CoordinationPerspectives on Economic Regulation in Europe and the United States, (1996) Clarendon Press Oxford. See Jeanne-Mey Sun and Jacques Pelkmans, "Regulatory Competition and the Single Market", (1995) 33 Journal of Common Market Studies, 67 especially at p.83.
} 
Over the past five years, concerns over good governance, understood in a broad sense, have considerably risen. A number of international organizations have, for instance, sought to promote the development of good governance principles throughout the world. $^{93}$ Similar preoccupations have also increased in the EC. In 2002, the Commission's White Paper on European Governance has identified a number of core principles of good governance, which include the requirements of independence, accountability, transparency and participation. ${ }^{94}$ As far as NRAs are concerned, such principles have generally been imposed in an ad hoc fashion through the insertion of specific requirements within the first and second generation directives. ${ }^{95}$

\subsubsection{The requirement of independence}

A fundamental obligation imposed by EC law on NRAs is that of independence. ${ }^{96}$ First generation liberalization directives explicitly referred to this concept with, however, some differences depending on the sector envisaged. As far as the telecommunications sector is concerned, first generation directives required the obligation of independence to be fulfilled. Article 7 of Directive $90 / 388$ on competition in the market for telecommunications services provided that MS had to ensure that from 1 July 1991 the grant of operating licences, the control of type approval and mandatory specifications, the allocation of frequencies and surveillance of usage conditions were to be carried out by an independent body of telecommunications operators. ${ }^{97}$ This requirement of independence was, however, not entirely new as it could already be identified in the case law of the ECJ. In GB-Inno-BM, the ECJ considered that in markets open to competition, the combination of regulatory and commercial functions amounted to a violation of Article 81(1) and 82 of the Treaty in so far as this delegation to an operator which has a dominant position for the supply of telecommunications equipment, constituted a strengthening of that dominant position. ${ }^{98}$ This judgement was confirmed in subsequent ECJ case-law and the separation of regulatory and commercial functions is now a wellestablished principle of EC law.

\footnotetext{
93 See supra note 14 .

${ }^{94}$ See Commission's White Paper on Governance, supra note 16. See also the various documents adopted by the Commission in June 2002 and in December 2002. Information on these documents is available at http://europa.eu.int/comm/governance/suivi lb en.htm

95 The liberalization of network industries in the EC has followed two stages. A first generation of directives were adopted to initiate liberalization in a variety of sectors (e.g., by abolishing exclusive rights, requiring unbundling of network activities and providing for interconnection duties, as well as transparency and non discrimination requirements). More recently, a number of directives referred to as second generation directives have been adopted or are currently being adopted in order to go further, i.e. to complete the liberalization process and remove the remaining obstacles to competition.

${ }^{96}$ The Commission has recently outlined the importance of this requirement in the Green Paper on Services of General Interest, supra note 41, Annex at pp.46-47.

97 See Commission Directive 90/388 on Competition in the Markets for Telecommunications Services, supra note 81 .

${ }^{98}$ See ECJ, 13 December 1991, RTT Vs. GB-Inno-BM, 18/88, supra note 28.
} 
In addition, some indications as to how MS should guarantee the independence of NRAs is provided for in the Amendment ONP Framework directive. ${ }^{99}$ Article 5.a.2 of directive 97/51 provides that:

"In order to guarantee the independence of NRAs, the latter shall be legally distinct from and functionally independent of all organisations providing telecommunications networks, equipment or services. Member State that retains ownership or a significant degree of control of organizations providing telecommunications networks and/or services shall ensure effective structural separation of the regulatory function from activities associated with ownership or control."

The first sentence of Article 5.a.2 which refers to the concepts of "legal" and "functional" separation", indicates how MS should proceed to ensure the independence of regulatory bodies vis-à-vis economic actors. Similar requirements of legal and functional separation can be found in the new framework directive. ${ }^{100}$ The second sentence of Article 5.a. 2 relates to situations where MS retain ownership o significant control of the incumbent. In such cases, MS should ensure that the Ministry/department responsible for the holding by the State in the incumbent are structurally separated from the bodies to which the regulatory functions have been devolved. "Structural" separation is necessary to ensure that regulatory decisions are not influenced by public ownership considerations. ${ }^{101}$

In the energy sector, the single obligation imposed by the first-generation directives (respectively Directive 96/92 for electricity and Directive 98/30 for gas) on MS was to create

"appropriate and efficient mechanisms for regulation, control and transparency so as to avoid any abuse of dominant position, in particular to the detriment of consumers and any predatory behaviour. These mechanisms shall take account of the provisions of the Treaty and in particular Article 82 thereof'. ${ }^{102}$

The new Directive 2003/54 concerning common rules for the internal market in electricity provides that Member States

\footnotetext{
${ }^{99}$ See Directive 97/51 of 6 October 1997 amending Council Directives 90/387 and 92/44 for the purpose of adaptation to a competitive environment in telecommunications, OJ L 295 of 29 October 1997, pp.23-34.

${ }^{100}$ See Article 3.2 of the Framework Directive, supra note 29, which reproduces the former 5.a.2 of the ONP Directive. As far as independence towards public authorities is concerned, see Communication from the Commission of 20 October 1995, COM(1995) 543 final. The latter requirement of "structural separation" between regulatory and commercial functions has not been immediately fully complied with by all MS. However, the situation has evolved and many MS have taken steps to ensure independence of the regulator with regards to public authorities. See Eighth Report of the European Commission at p.18, supra note 88 .

101 The requirement of structural separation is also provided for at Article 3.2 of the Framework Directive, supra note 29.

${ }^{102}$ See Article 22 of Directive 96/92 in the electricity sector, supra note 72 and Article 22 of Directive $98 / 30$ in the gas sector, supra note 72 .
} 
"shall designate one or more competent bodies with the function of regulatory bodies. These authorities shall be wholly independent from the interests of the electricity industry". ${ }^{103}$

This provision goes slightly beyond the first-generation directives in that it requires MS to designate one or more regulatory bodies, instead of simply putting into place "appropriate and efficient mechanisms for regulation" as was initially requested. It is not clear whether this provision prohibits a MS from designating a competition authority as the energy regulator or to create an energy regulator within the competition authority. ${ }^{104}$ This provision also requires that the designated authorities be "wholly independent from the interests of the electricity industry". It does not, however, require that such authorities be independent from political authorities.

As far as the rail transport sector is concerned, requirements of independence can be identified in Directive 2001/14 on the allocation of railway infrastructure capacity and the levying of charges for the use of railway infrastructure and safety. ${ }^{105}$ First, this directive contains a provision saying that the infrastructure manager (i.e., the company which owns and maintains the railway tracks) should take care of the capacity allocation processes (i.e., the allocation of train paths) and pursue that mission on a fair and nondiscriminatory basis and in accordance with EC law. This provision, however, provides that

"where the infrastructure manager, in its legal form, organisation or decisionmaking functions is not independent of any railway undertaking, the functions (....) described in this chapter shall be performed by an allocation body that is independent in its legal form, organisation and decision-making from any railway undertaking". ${ }^{106}$

Second, the directive requires that MS establish a regulatory body, which

"can be the Ministry responsible for transport matters or any other body, shall be independent in its organisation, funding decisions, legal structure and decisionmaking from any infrastructure manager, charging body, allocation body or applicant". ${ }^{107}$

In line with the jurisprudence of the ECJ and the approach taken in other sectors, these directives thus seek to ensure a separation between commercial and regulatory

\footnotetext{
103 See Directive 2003/54 concerning common rules for the internal market in electricity and repealing Directive 96/92, supra note 72 at Article 23.

${ }^{104}$ On this issue, see text accompanying notes 87.

${ }^{105}$ See Directive 2001/14 of 26 February 2001 on the Allocation of Railway Infrastructure Capacity and the Levying of Charges for the Use of Railway Infrastructure and Safety Certification, OJ L 75/29 of 15 March 2001.

${ }^{106}$ See Id. at Article 4(2).

${ }^{107}$ See Id. at Article 30(1).
} 
functions. ${ }^{108}$ Unlike in the electronic communications sector, nothing is done to protect the regulatory body from political interferences, as the directive allows MS to decide that the body be the Ministry in charge of transport. This gives carte blanche to the government to interfere with transport policy. In addition, the directive seems to allow MS to create two separate bodies, i.e. the allocation body, which needs to be created when the infrastructure manager is linked to a railway undertaking, and the regulatory body. This approach, which, for instance has been followed in Belgium leads to unnecessary expenses and a proliferation of agencies. ${ }^{109}$

In sum, the degree of independence that is promoted by EC law varies from one sector to the next. In general, however, the directives leave a lot of leeway to the MS on how to ensure the independence of their regulatory agencies. For instance, directives are silent when it comes to prevent the conflict of interests that may arise when commissioners hold interests in undertakings they are called to regulate, or the so-called "revolving doors" practices that we can sometime observe when commissioners end their appointments. ${ }^{110}$ However, the devil is often in the details and broad requirements of independence might not do much to ensure the absence of capture of regulatory agencies by commercial or political interests. Moreover, liberalization directives tend to be more severe when it comes to protect regulator from undue influence from industry than to protect regulators from political interferences. This is regrettable as one of the main historic reasons for creating regulatory agencies was to remove politically-sensitive issues from the hands of the government.

\subsubsection{The requirement of accountability}

EC law also imposes some degree of accountability on the NRAs. Indeed, the fact that NRAs need to be independent should not be an excuse to exempt them from any form of control. A balance must be struck between independence and accountability. To ensure regulators' accountability, several measures can be adopted.

\footnotetext{
${ }^{108}$ As far as the postal sector is concerned, a similar requirement can be found in Article 22 of Directive 97/67: "Each Member State shall designate one or more national regulatory authorities for the postal sector that are legally separate from and operationally independent of the postal operators. Member States shall inform the Commission which national regulatory authorities they have designated to carry out the tasks arising from this Directive. The national regulatory authorities shall have as a particular task ensuring compliance with the obligations arising from this Directive. They may also be charged with ensuring compliance with competition rules in the postal sector". See Directive 97/67 of 15 December 1997 on common rules for the development of the internal market of Community postal services and the improvement of quality of service, OJ L 15 of 15 December 1997, pp.14-25.

${ }^{109}$ The proliferation of agencies in the railway sector may further increase. The Commission's proposal for a directive on safety on the Community's railways requires MS to establish safety authorities to regulate railway safety. Similar requirements of independence would apply to these authorities. See Article 15 of Proposal for a Directive of the European Parliament and of the Council on safety on the Community's railways and amending Council Directive 95/18 on the licensing of railway undertakings and Directive $2001 / 14$ on the allocation of railway infrastructure capacity and the levying of charges for the use of railway infrastructure and safety certification, OJ C 126 of 28 may 2002, pp.332-350.

${ }^{110}$ See W. Smith, supra note 22.
} 
A first measure is the setting up of procedures whereby the performance of regulators is reviewed independently and assessed against specific objectives. ${ }^{111}$ Unfortunately, EC liberalization directives do not provide for a periodic review of the NRAs' activities. ${ }^{112}$ It could nevertheless be observed that the Commission's yearly reports on the implementation of the regulatory frameworks generally assess the performance of the NRAs. These assessment mechanisms are, however, limited as they merely review the compliance of the NRAs with the substantive obligations laid down in the respective directives and do not raise the question whether reliance on NRAs is still justified. Thus, the review cannot lead to major institutional changes (e.g. such as a dismantlement of the NRAs if the output proves unsatisfactory). In this context, the adoption of a mechanism for the periodic review of the NRAs' activities would constitute a major improvement. Several elements should be provided for. A first element would be the adoption of a clear timetable for the review of the output of the NRAs. In addition, the grounds of review as well as the criteria for assessment should be precisely and objectively defined in the framework legislation. Finally, the outcome of the review shall lead to the adoption of decisions such as a dismantlement of the NRA if the assessment reveals that it is no longer necessary (e.g., when some pre-determined factors are triggered such as the disappearance of all major bottlenecks requiring regulatory intervention) or, more likely, a redefinition of its powers and duties in case its output proves unsatisfactory.

Second, it must be ensured that regulators publish reports on their activities and the way in which they use their financial resources. Such obligations have generally not been provided for by first generation directives. Reporting requirements have subsequently been inserted in second generation directives but only in the electricity and in the gas sectors. In the case of the electricity sector, Article 23 of directive 2003/54 requires that the NRAs

"publish an annual report on the outcome of their monitoring activities [with regards to] the rules on the management and allocation of interconnection

\footnotetext{
${ }^{111}$ Interestingly, the new regulatory framework for electronic communications does provide for a review system whereby regulatory requirements can only be imposed or maintained on operators holding significant market power as long as they are necessary to correct a market failure. See recital 27 of the preamble of the Framework Directive, supra note 29: "It is essential that ex ante regulatory obligations should only be imposed where there is not effective competition, i.e. in markets where there are one or more undertakings with significant market power, and where national and Community competition law remedies are not sufficient to address the problem". See Damien Geradin and Gregory J. Sidak, "Remedies and the Institutional Design of Regulation in Telecommunications in the United States and the European Union", to be published in the Handbook of Telecommunications Economics, $2^{\text {nd }}$ Vol. This procedure permits to review the necessity of maintaining regulatory requirements, but in no way allows assessing the performance of the regulator against predetermined objectives.

112 Instead, EC legislation only provides for the review of the substantive framework. In the telecommunications sector, the framework directive only provides for a periodic review of the substantive provisions of the directive. See recital 39 of the preamble of the Framework Directive, supra note 29: "The provisions of this directive should be reviewed periodically, in particular with a view to determining the need for modification in the light of changing technological or market conditions".
} 
capacity, in conjunction with the regulatory authority or authorities of those Member States with which interconnection exists". ${ }^{113}$

In addition, reporting requirements to parliamentary committees may also lead to more intense scrutiny than reporting requirements towards ministers. ${ }^{114}$ This is particularly true in sectors that were previously under the supervision of the State administration.

Last but not least, control mechanisms allowing a judicial review of the regulatory decisions adopted by NRAs must be instituted. In the EC legal system, judicial controls of the NRAs can be achieved in two different ways. First, under national law, the NRAs generally fit within the overall framework of administrative law. Depending on the judicial structure of each MS, their decision can be challenged before ordinary courts of law or special administrative tribunals. National courts will normally ensure that the decisions of NRAs comply with the requirements of national law. They may also review NRA decisions under EC law and in particular, the competition law provisions of the EC Treaty. ${ }^{115}$ However, this may not always be the case. EC directives contain some limited requirements regarding the judicial review of the NRAs. In the telecommunications sector, for instance, the framework directive requires that MS put in place an "effective" procedure of appeal which allows for a party affected by the decision adopted by a NRA to have this decision reviewed. ${ }^{116}$ Some precisions as to the nature of the controlling body are also provided for. ${ }^{117}$ In other sectors, EC legislation leaves more discretion to MS in that it is only required that MS "designate a competent authority, which must be independent of the parties, to settle disputes relating to the contracts and negotiations in question. In particular, this authority must settle disputes concerning contracts,

\footnotetext{
${ }^{113}$ See Article 23 of Directive 2003/54, supra note 72. A similar requirement can be found in the gas sector at Article 25 of Directive 2003/55, supra note 72. However, no such requirements have been imposed in the field of electronic communications. In the railway sector, the proposal for a directive on safety on the Community's railways requires that the national safety authorities report annually on their activities before the European Railway Agency. A specific provision is dedicated to the reporting requirements. See Article 17 of the Proposal for a Directive on safety of Community's railways, supra note 109.

${ }^{114}$ See P. Nicolaides, A. Geveke and A.M. den Teuling, supra note 4 at p.69.

115 Pursuant to the principle of "procedural autonomy", in the absence of Community rules on the subject at stake, it is for the domestic legal system of each MS to designate the courts having jurisdiction and to determine the procedural conditions governing actions at law intended to ensure the protection of the rights which citizens enjoy by virtue of the direct effect of community law. See ECJ, 16 December 1976, ReweZentralfinanz eG et Rewe-Zentral AG v Landwirtschaftskammer für das Saarland, 33/76, ECR 1976, p.1989. See on this principle, Michel L. Struys, "Le droit communautaire et l'application des règles procédurales nationales", (2000) 67 JT Droit Européen, 1.

${ }^{116}$ See Framework Directive, supra note 29 at Article 4: "Member States shall ensure that effective mechanisms exist at national level under which any user or undertaking providing electronic networks and/or services who is affected by a decision of a national regulatory authority has the right to appeal against the decision to an appeal body that is independent of the parties involved". This requirement already existed at Article 5.a.3 of Directive 97/51 of the European Parliament and of the Council amending Council Directives 90/387 and 92/44 for the Purpose of Adaptation to a Competitive Environment in Telecommunications, supra note 99 .

${ }^{117}$ See recital 12 of the preamble of the Framework Directive, supra note 29.
} 
negotiations and refusal of access or refusal to purchase". ${ }^{118}$ Finally, in the postal and in the rail sectors, EC legislation does not provide any requirement to set up judicial review mechanisms at the national level.

Second, the Commission may also act as a controlling body. It can issue reasoned opinions pursuant to Article 226 of the EC Treaty (ex-article 169) if it considers that a NRA decision violates EC Law. The lack of compliance by the MS in question may serve as a basis for the initiation of legal proceedings by the Commission before the ECJ. ${ }^{119}$ The latter mechanism, however, is less than perfect. Indeed, given that the infringement procedure is not directed to the NRA but to the MS in which it operates, the former seems to enjoy a certain degree of immunity. Of course, the MS will generally ask the NRA to bring its actions in line with EC law. But this situation creates a tension with the requirement of independence between the government and the NRA as it implies that the government ends up giving instructions to the NRA. Another limitation of this approach is that, from a policy-making perspective, infringement proceedings are unlikely to be initiated by the Commission. In sectors where the "networking" pattern has been followed (such as, for instance, the telecommunications sector), the NRAs are the arm of the Commission for bringing about market liberalisation. Thus, the development of conflictual relationships between the Commission and the NRAs may in the long run compromise vital collaboration between both levels. In addition, the initiation of formal legal proceedings may affect the credibility of the NRA with regards to the regulated entities.

\subsubsection{Transparency}

There are two main facets to this principle. First, all regulatory bodies should follow clear, simple and objective processes and should be open with stakeholders about their objectives, methodologies and data, subject to a confidentiality requirement. Second, information about the outcome of such processes (e.g., regulations or decisions) should be easily accessible by all stakeholders, for instance through an obligation of publication and motivation of regulatory decisions.

Some requirements relating to transparency can be found in first-generation directives. For instance, Article 9.5 of the Interconnection Directive provides that when a NRA takes a decision to resolve an interconnection dispute between operators, it shall make its decision public and the parties must be given a full statement of the reasons upon which it

\footnotetext{
${ }^{118}$ See Directive 96/92 concerning Common Rules for the Internal Market in Electricity supra note 72 and Directive 98/30 concerning Common Rules for the Internal Market in Natural Gas, supra note 81, respectively at Articles 20(3) and Article 21.

${ }^{119}$ In practice, the ECJ and the CFI have never had the opportunity of ruling that a MS infringed EC law because of unlawful action by a NRA. However, there is nothing to prevent that a MS be held liable for unlawful action by a NRA. Indeed, the ECJ's case law makes a very broad interpretation of the categories of public entities that can, on behalf of a MS, be held liable of an infringement of EC law on the basis of Article 226. See Denys Simon, Le système juridique communautaire, 3 ed., PUF, pp.617-619.
} 
is based. ${ }^{120}$ As in the case of accountability, in other sectors, first-generation directives do not contain any requirement regarding the transparency of national regulatory agencies, even if, once again, such requirements have often been adopted at the MS level. The new telecommunications regulatory package has not engendered substantial improvements with respect to transparency mechanisms. However, a limited exception can be found in the Framework Directive, which contains several provisions ensuring that regulatory processes comply with principles of regulatory governance. For instance, this directive provides that MS "shall ensure that national regulatory authorities exercise their power impartially and transparently" and that "acting in accordance with national rules on public access to information and subject to Community and national rules on business confidentiality, national regulatory authorities publish such information as would contribute to an open and competitive market". ${ }^{12}$

Yet, a noticeable recent evolution should be noted. In the field of rail, the recent Commission's proposal for a Directive on safety on the Community's railways provides for the creation of safety authorities at the national level. Interestingly, a provision of the Directive entitled "decision-making principles of the safety authority" lays down a variety of transparency requirements:

"The safety authority shall carry out its tasks in an open, non-discriminatory and transparent way. In particular it shall allow all parties to be heard and give reasons for decisions. It shall promptly respond to requests and applications and communicate its requests for information and its decisions without undue delay." 122

This evolution, though limited, reveals the Commission's increasing concern for the compliance of NRAs with good governance principles in the decision-making processes. It should thus be welcomed.

\subsubsection{Participation}

According to the principle of participation, NRAs should be encouraged to allow formal consultation (e.g. through written comments and/or public hearings) of stakeholders before decisions are made. None of the first-generation directives contained provisions designed to ensure the participation of stakeholders in regulatory processes. Except in the case of the new telecommunications regulatory package, second-generation liberalizing

\footnotetext{
${ }^{120}$ See Directive 97/33 of 30 June 1997 on Interconnection in Telecommunications with regard to ensuring Universal Service and Interoperability through Application of the Principles of Open Network Provision (ONP), supra note 36.

${ }^{121}$ See Article 3(3) and 5(4) of the Framework Directive, supra note 29.

${ }^{122}$ See Article 16 of the Proposal for a Directive of the European Parliament and of the Council on safety on the Community's railways and amending Council Directive 95/18 on the licensing of railway undertakings and Directive 2001/14 on the allocation of railway infrastructure capacity and the levying of charges for the use of railway infrastructure and safety certification, supra note 109. This provision will probably be adopted as such. There is now a Common Position on the Commission's Proposal and the wording of Article 16 has not been challenged by the Council and the EP. See Common Position 55/2003 of 26 June 2003, OJ C 270E of 11 December 2003, pp.25-47.
} 
directives do not deal with this issue either. The Framework Directive states that MS shall ensure that where national regulatory authorities intend to take measures in accordance with this directive or specific directives which have a significant impact on the relevant market, they give interested parties the opportunity to comment on the draft measure within a reasonable period. ${ }^{123}$ If such measures allow stakeholders to take part in the regulatory process, this form of participation remains weak. Indeed nothing is stated as to how NRAs should take into account the results of this public consultation. Moreover although the results of the consultation procedure shall be made publicly available by the NRA, it may decide in some cases not publish these results for reasons of confidentiality. ${ }^{124}$

Recent proposed legislation suggests that the Commission is increasingly willing to improve compliance of NRAs with participation principles. This evolution can be seen in the proposed Directive on safety on the Community's railways whose Article 16 requires that

"In the process of developing the national regulatory framework the safety authority shall consult all involved and interested parties, including infrastructure managers, railway undertakings, manufacturers and maintenance providers, users and staff representatives." $" 125$

In conclusion, wide disparities continue to exist between NRAs when it comes to compliance with the principles of good governance identified above. These disparities can be observed between sectors, as well as between MS. First, as far as sectors are concerned, the new electronic communications Framework Directive, for instance, provides for a higher degree of protection against political interferences than Directive $2001 / 14$ on the allocation of rail infrastructure. ${ }^{126}$ This situation seems paradoxical since rail is a much more politically-charged sector than telecommunications and thus a high degree of protection against political interferences would be desirable in this sector. Clearly, the rail directive reflects a political compromise designed to reassure MS having large, highly-unionized (and, often, overstaffed and loss-making) public rail companies, the future of which they want to continue to control. Similar disparities also exist with respect to other principles of good governance such as accountability, transparency, and participation. Second, because of the extremely general character of the obligations imposed in the liberalization directives, disparities will also exist between the national situations. One could of course argue why it matters that the French energy regulator be submitted to less stringent requirements of good governance than its German counter-part or vice-versa? This will certainly matter to cross border operators, which will have to operate under a multiplicity of regimes and when their procedural rights will vary from one place to another. Moreover, given the significance of procedural issues, companies

\footnotetext{
${ }^{123}$ See Article 6 of the Framework Directive supra note 29.

${ }^{124} \mathrm{Id}$.

125 See Proposal for a Directive on safety on the Community's railways and Common Position 55/2003, supra notes 109 and 122 .

${ }^{126}$ See Directive 2001/14, supra note 105.
} 
operating under an open, operator-friendly regime will be given a substantial advantage compare to those acting under a heavier, or more hostile regulatory environment.

3. Fine-tuning the institutional regulatory parameters

The preceding analysis leads to the conclusion that the institutional regulatory parameters shall be fine-tuned.

\subsection{The level of regulation in network industries}

As we have seen, it can reasonably be argued that there would be important benefits to the creation of European regulatory agencies in areas such as telecommunications or energy. These sectors are ridden with externalities and the approach taken by the Commission to ensure a certain policy coherence among NRAs (i.e., the creation of networks and discussion fora) provide only partial substitutes to the creation of fullyfledged European regulatory agencies.

The failure to create such agencies is partly due to politics. As public choice theorists have abundantly demonstrated public, like private, entities have their own selfish agenda and will generally use various tools to maintain or expand their spheres of influence. ${ }^{127}$ Clearly, the Commission and the Council fear that their spheres of influence in a range of sectors be partly eaten away by European regulators. ${ }^{128}$ As academics, there is little we can do to influence politics. Yet, we can propose strategies to overcome legal obstacles to the creation of European regulatory agencies. As we have shown above, the Meroni doctrine has often been invoked by the Commission as a reason preventing the setting up of European regulatory agencies. ${ }^{129}$ We believe, however, that several methods of interpretation could be proposed for neutralizing the application of the Meroni ruling. It could, for instance, be considered that the granting of implementation powers to agencies does not amount to a delegation of power from an EC institution to a regulatory authority but rather to the "Europeanization" of powers traditionally belonging to national administrations. ${ }^{130}$ Another approach would be to say that the creation of European regulatory agencies would allow the EC institutions to focus on their core (legislative) competencies and thus improve the institutional balance of the EU.

These arguments have been endorsed by a large number of authors in order to support calls for a more dynamic interpretation of the Meroni doctrine and one author has even argued that this doctrine had "de facto been overruled". ${ }^{131}$ Although we tend to subscribe

\footnotetext{
${ }^{127}$ See, for instance, James M. Buchanan, The Limits of Liberty, (1975) Chicago University Press.

${ }^{128}$ For instance, a number of authors have underlined the fact that the Commission and the Council were reluctant to deal with the question of the creation of a European telecommunications operator and that they were forced to put the issue on the agenda following the persistence of the EP during the legislative procedure. See G. Majone, supra note 36 and Pierre Larouche, "A Closer Look at Some Assumptions Underlying EC Regulation of Electronic Communications", (2002) 3 Journal of Network Industries, 129.

${ }^{129}$ See supra at 2.1.

${ }^{130}$ Such idea is formulated by several commentators. See R. Dehousse supra note 4 and M. Everson, supra note 4 at p.10. See also X. Yataganas, supra note 4 at p.40, speaking of the "Europeanization of powers".

${ }^{131}$ See G. Majone, supra note 1 at p.289.
} 
to these theories, we have to acknowledge that the ECJ's ruling in Meroni still reflects content of the law as it stands and that the restrictive conditions set by the Court are still valid. ${ }^{132}$ Wide delegations of power to external bodies remain impossible unless the Court explicitly overrules this judgment. ${ }^{133}$ Hence, the removal of the Meroni legal obstacle firmly lies in the ECJ's hands. ${ }^{134}$ As long as the Court is not called upon to rule on this issue, the dynamic interpretation of the case law we propose will be of limited assistance. This does not mean, however, that Meroni should stand forever as an obstacle. Two alternative options may indeed be explored.

A first approach would be to opt for a Treaty modification. ${ }^{135}$ In this respect, two options may be explored. First, an amendment of Article 7 of the Treaty could be suggested whereby this provision would refer to the European Regulatory Agencies next to the Council, the Commission, the EP, the ECJ and the Court of Auditors. This is the "cutting edge" option. It presents the obvious advantage of solving the problem of institutional balance as agencies would be included within institutions and thereby integrated in the "balance" of powers. The main disadvantage of this solution is that it may be too ambitious as it would place agencies at the same level as the EP, the Council, the Commission, the ECJ and the Court of Auditors, an option that was rejected for the ECB, which was instead provided for in a specific provision (Article 8 of the EC Treaty). ${ }^{136}$ Second, another option would be the insertion of a specific legal basis in the Treaty for the creation of agencies, as well as a reference to the procedure to be followed for their setting up. ${ }^{137}$ This solution has the advantage of being politically less sensitive. In addition, the practice of the "constitutional validation" has already been implemented in the EC legal order in the context of the comitology, which had developed praeter legem and that was subsequently upheld through a Treaty modification. ${ }^{138}$ However, this option raises a legal problem as it would still be questionable whether the adoption of a specific Treaty provision would suffice to create EAs with discretionary powers. As this would not modify the equilibrium contained in Article 7, the principle of "institutional balance" as interpreted in the Meroni case would continue to apply. This is implicit in the Communication from the Commission on the institutional architecture, where the Commission advocates the creation of a specific legal basis for agencies but meanwhile considers that these agencies would still be prevented from exercising a discretionary power. ${ }^{139}$

\footnotetext{
${ }^{132}$ See K. Lenaerts, supra note 4 at p. 46 .

${ }^{133}$ Id. at pp.41 and 46.

${ }^{134}$ See M. Everson, supra note 4 at p. 198 .

${ }^{135}$ See K. Lenaerts, supra note 4 at p.42 See G. Majone supra note 1 at p.276. See E. Vos supra note 4 at p.1124.

${ }^{136}$ See G. Majone supra note 1 and 4.

${ }^{137}$ See, for instance, E. Vos supra note 4 at p. 1124.

${ }^{138}$ On the practice of "constitutional validation", see Koen Lenaerts and Amaryllis Verhoeven, "Towards a Legal Framework for Executive Rule-Making in the EU? The Contribution of the New Comitology Decision", (2000) 3 Common Market Law Review, 645 at p.646.

${ }^{139}$ See Communication from the Commission, infra note 140 at p.13. A solution to overcome this difficulty would be to recognise explicitly, in the specific Treaty provision, that EAs can exercise discretionary powers.
} 
The Convention for the future of Europe (which had been mandated to elaborate a new constitutional text for the EU) provided a window of opportunity for the removal of the hindrance brought about by the Meroni case. The adoption of a specific legal basis for the creation of regulatory agencies was, in particular, supported by the Commission. The Commission's proposal was however limited as it provided that: the "agencies cannot be given either the responsibilities which the Treaty assigns directly to the Commission, nor decision-making powers in areas in which they would be required to arbitrate in conflicts between public interests, nor can they exercise political appraisal powers or make complex economic assessments". ${ }^{140}$ Eventually, the Convention did not succeed in achieving a consensus on this issue and, as a result, agencies were left out from the final draft Constitution. Of course, a variety of limited references to agencies were inserted in the text (i.e. with respect to the rules governing legal proceedings, the activities of the European Ombudsman, the right of access to documents and the protection of personal data), but they essentially remain of a cosmetic nature. ${ }^{141}$ One will thus have to wait for another opportunity to further explore this option. This opportunity may come sooner than initially expected as the failure of the Heads of States to agree on the text of the Convention at their meeting on 13 December 2003 in Brussels might open a window of opportunity to renegotiate some of the issues.

A second approach would consist in adopting of a piece of secondary legislation (for instance, a Regulation) that would provide a framework for the creation of regulatory agencies. In the short run, the adoption of a transversal act of this kind is the most realistic option. Ideally, such an act would detail the conditions pursuant to which agencies can be set up at the EC level. The limitation inherent to this approach is that a piece of secondary legislation could in no way overrule Meroni. Thus, this approach would not allow the setting up of agencies enjoying real regulatory powers.

Rather than adopting a Regulation, the Commission has shown support for the conclusion of an inter-institutional agreement on European regulatory agencies. ${ }^{142}$ This act, however, would not deal with the issue of whether agencies at the European level can be granted

\footnotetext{
${ }^{140}$ See Communication from the Commission to the European Convention on the Institutional Architecture, "For the European Union, Peace, Freedom, Solidarity" COM(2002) 728 final of 11 December 2002. A similar proposal had also been formulated in the feasibility study (known under the name of "Penelope" project) prepared by some Commission's officials under the responsibility of President Prodi. At Article 71, the Penelope project provided a legal basis for the setting up of EAs, but limited their role to "exercising tasks of programme management for the Union or for providing scientific expertise". They could also be given responsibility for taking decisions for the application of laws".

${ }^{141}$ With respect to legal proceedings, the draft constitution realizes a number of improvements: see Article III-270 (annulment proceedings), Article III-270 al.1. (reviewable acts), Article III-272 (failure to act proceedings) and Article III-273 (compliance with ECJ rulings) of the proposed constitution. The acts of agencies that are intended to produce legal effects vis-à-vis third parties are thus challengeable on the basis of annulment proceedings. As far as the activities of the European Ombudsman, the right of access to documents and the protection of personal data are concerned, see respectively, Article 48, Article 49 and Article 50 of the Draft Constitution.

${ }^{142}$ See Communication from the Commission, "Better Law Making", supra note 19 at p.5. For reasons of transparency, it could be considered that the choice of a classic enforceable instrument listed in the 'nomenclature' such as a regulation should be preferred.
} 
true regulatory powers. ${ }^{143}$ The Commission indeed sticks to a narrow interpretation of the Meroni doctrine. Thus, an act of this kind would only be of interest for the EAs.

\subsection{Optimal level of homogeneity among NRAs}

At present, there are significant differences in the way NRAs are organized in the MS. As we have seen, the freedom of the MS to organize their NRAs according to their preferences has allowed them to experiment distinct institutional arrangements. As one of us has written elsewhere, such a process of experimentation may eventually lead to convergence as best practices will eventually triumph and widely disseminate. ${ }^{144}$ This convergence process may, however, take time and in tightly coordinated markets where inconsistent regulatory approaches may be a source of distortions more pro-active measures to disseminate good practices may be necessary.

After ten years of institutional experimentation in some sectors, it is perhaps now time to draw some conclusions. Obviously, some institutional approaches have worked better than others and MS could certainly learn from the success or failures of their neighbours. We are not suggesting here that "bullet proof" solutions are now available. Even if they existed, procedural harmonization taking the form of a binding piece of legislation, such as a Regulation, would be desirable or politically achievable. In addition, it could be argued that it would violate the MS "institutional autonomy". ${ }^{145}$ Greater coherence and institutional improvement could, however, be achieved with the adoption of a "soft law" instrument, such as a Communication from the Commission, which would provide a set of options available to MS when designing agencies, as well as putting into evidence a set of best institutional practices. This could certainly help guide reforms at the national level.

\subsection{Principles of good governance}

It is extremely hard to know whether NRA actions in the various liberalized sectors comply satisfactorily with the principles of good governance outlined above. As we have seen, the liberalization directives only provide for limited good governance obligations on the NRAs created/to be created by the MS. It is thus essentially at the MS level that such obligations are imposed through the transposition legislation, a situation that creates important disparities between MS. The Commission's Green Paper on Services of General Interest released in July 2003 reveals some difficulties as to the compliance of NRAs with the principles of good governance. ${ }^{146}$ In the telecommunications sector, for instance, a number of NRAs do not meet the required standards of participation and

\footnotetext{
${ }^{143}$ See infra at 2.2.3.

${ }^{144}$ See D. Geradin, supra note 2 at p.22. See also J. McCahery, supra note 44.

${ }^{145}$ See M.L. Struys, supra note 115. Also, it has been observed that it is all the more doubtful that the founding Treaties grant the power to the EC to enact instruments that would amount to codified rules of administrative law. See S. Kadelbach, "European Administrative Law and the Law of a Europeanized Administration" in R. Dehousse and C. Joerges, supra note 15.

${ }^{146}$ See Green Paper on Services of General Interest, supra note 41, Annex at pp.46-47.
} 
accountability. ${ }^{147}$ For instance, it is reported that in Greece and Ireland, NRAs do not sufficiently take into account the comments made during consultation procedures. In Sweden, the NRA does not give the necessary time to operators to respond in consultation procedures. Also, in some MS, the Commission criticizes the dispute resolution procedures in that they are lengthy (Finland) or too elaborate (France).

We believe that good governance principles are essential components of sound (economic) regulation and that additional measures should be taken at the EC level to ensure that these principles, as defined above in this paper, should be fully complied with. Several approaches could be explored to reach this objective. A first approach would be to impose stronger good governance requirements in the liberalization directives. As we have seen, the second generation directives are more specific than the first generation directives regarding good governance. ${ }^{148}$ We believe, however, that additional obligations could still be inserted in these directives. In this respect, the Commission's recent proposal in the field of safety on the Community's railways seems to announce a positive evolution. The proposed directive on safety on the Community's railways contains a provision on the "decision-making principles" to be followed by the NRAs. ${ }^{149}$ The requirements it contains essentially relate to transparency, openness and participation concerns. As pointed out, this recent development should be welcomed. However, it is still too limited as no progresses are made with regards to independence and accountability. Also, the obligations contained with regards to transparency and participation are not far reaching in terms of substance. ${ }^{150}$

A second approach would be to adopt a regulation imposing a set of good governance requirements to be implemented by the MS. The advantages of this horizontal approach whereby a legislative instrument would specifically address this matter across sectors, is that it would underline the importance of this matter and would also ensure a minimum coherence across sectors. Indeed, while substantive issues of regulation (e.g. access to essential infrastructures) may require sector-specific treatment, we see no reason why varying principles of good governance should apply in the different sectors.

A third approach, which would be in line with the solution we proposed in the prior section, would amount to adopting a "soft law" instrument, such as a communication or a set of guidelines that would contain a list of best practices in terms of good governance. This document could be consolidated with the soft law instrument we proposed to ensure a greater level of homogeneity in the institutional options chosen by MS when creating NRAs. The advantage of this approach is that it would be faster and easier than the

\footnotetext{
${ }^{147}$ See Eighth Report on the Implementation of the Telecommunications Regulatory Package, supra note 88.

${ }^{148}$ In general, second generation directives are considered to be more intrusive with respect to institutional matters. See P. Nicolaides, A. Geveke and A.M. den Teuling, supra note 4 at p.63.

${ }^{149}$ See Proposal for a Directive on the safety on the Community's railways and Common Position 55/2003, supra notes 109 and 122 at Article 16.

${ }^{150}$ In addition, it is still too early to know whether this approach will become binding law, given that the proposed directive is still being negotiated by the Council and the EP. However, as was explained above, both institutions seem to agree on the wording and content of the provision dedicated to the decisionmaking principles.
} 
adoption of a piece of legislation. On the other hand, its weakness is that soft law instruments have no binding force and thus could have limited influence on the institutional regulatory practices in the MS.

\section{The European Agencies (EAs)}

It is now time to move one level up and discuss EAs. Our discussion in Part II has shown that there is a large number of interactions between the national and Community levels and some of the discussions regarding EAs have already been carried out in that part. This part will, however, specifically focus on the issues raised by the EAs. It will follow the same structure as Part II, but will often reach different conclusions. As will be seen, the development of EAs in the EC has not followed a symmetrical pattern to that of the NRAs (1). Also, the review of the institutional regulatory parameters leads to findings different from those governing the NRAs (2). It is, however, clear that an adaptation of these parameters is also required (3).

\section{The formation of EAs at the EC level}

The emergence, over the past ten years, of new entities within the European administrative system constitutes significant development in the evolving institutional architecture of the EC. ${ }^{151}$ These entities are claimed to offer several advantages, which may explain their expansion in the EC legal order. ${ }^{152}$ First, they would lighten the workload of other EC institutions, which could in turn focus on their core strategic functions. ${ }^{153}$ Second, they would remove the resolution of technical issues from political pressures, thereby securing policy consistency over time. Third, the duty to resolve technical problems would be left to specialists thereby contributing to reducing asymmetries of information between the operators and the administration. Fourth, the setting up of European wide agencies would reduce transaction costs and ensure neutrality regarding national interests. Finally, the clarification of the competences that would result from the creation of agencies (political and strategic duties to the

\footnotetext{
${ }^{151}$ The creation of agencies has not been limited to the EC legal framework. One agency has been created under the Euratom Treaty (the Euratom Supply Agency), and four under the second and third pillars (European Union Institute for Security Studies, European Union Satellite Centre, European Police OfficeEuropol, and Eurojust). A further agency might be instituted under the third pillar (i.e. justice and home affairs). Recently, the Commission adopted a proposal for a Council Regulation establishing a European Agency for the management of operational cooperation at the European Union's external borders (land and maritime borders as well as international airports). The agency will assist MS in implementing EU legislation concerning border control and surveillance, but also concerning the return of third-country nationals who are not allowed to stay in the EU. See Press Release, IP/03/1519 of 11 November 2003. For the purposes of this article, reference will only be made to the EC Agencies.

152 An important number of authors have highlighted the benefits resulting from the creation of EC Agencies and have thus shown support the creation of further EAs. See for instance, R. Dehousse, M. Everson, G. Majone, E. Vos and X. Yataganas, supra note 4.

${ }^{153}$ See, for instance, L. Grard, supra note 4 at p.5, who considers that in the field of transport, the Commission decentralizes technical matters to agencies in order to re-focus on its core missions.
} 
Commission - technical tasks for the agencies) would in turn contribute to a better understanding of the EC by its citizens. ${ }^{154}$

The agencies currently in existence have been set up in three waves. ${ }^{155}$ A first generation of agencies was set up in the 1970s. This is the case of the European Centre for the Development of Vocational Training (the "Cedefop") and the European Foundation for the Improvement of Living and Working Conditions (the "EUROFOUND"). ${ }^{156}$ This initial movement towards "agencification" was not a major institutional evolution for two reasons. First, it only led to the creation of two agencies enjoying limited powers in very specific fields. Second, it did not last very long. No further agencies were created during the 25 years that followed.

The second wave of agencies started in the early 1990s with the creation of the European Environment Agency (the "EEA") and the European Training Foundation (the "ETF") 157 In contrast with the first wave, this latter "agencification" movement constituted a more striking evolution for the EC administration. First, in terms of quantity, six additional agencies were created in the four years following the creation of the EEA and the ETF, as well as two more in the end of the nineties. ${ }^{158}$ Second, these agencies deal with diverse

\footnotetext{
154 The existence within the same institution of both regulatory and political objectives pleads for the institution of further agencies at the EC level. The danger of politicization of regulation has been pointed out by G. Majone in the context of competition policy. See G. Majone, supra note 4 . This opinion is not shared by Steinberg who supports the idea the politicization of the Commission is a good thing and supports the Commission's reluctant stance on the establishment of further regulatory agencies. See P. Steinberg, supra note 4 at pp.16-17.

${ }^{155}$ See X. Yataganas, supra note 4 at p.23.

156 The Cedefop was established in 1975 by Council Regulation 337/75, OJ L 39 of 13 February 1975, pp.1-4. The EUROFOUND was established in 1975 by Council Regulation 1365/75 of 26 May 1975, OJ L 139 of 30 May 1975, pp.1-4.

${ }^{157}$ The EEA was established by Council Regulation 1210/90 of 7 May 1990, OJ L 120 of 11 May 1990, pp.1-6, amended by Council Regulation 933/1999 of 29 April 1999, OJ L 117 of 5 May 1999, pp.1-4. The ETF was established by Council Regulation No 1360/90 of 7 May 1990, OJ L 131 of 23 May 1990, pp.1-5. On the EEA, see Peter G.G. Davies, "The European Environment Agency", (1994) 14 Yearbook of European Law, 313; David. A. Westbrook, "Environmental Policy in the European Community: Observations on the European Environment Agency", (1991) 15 Harvard Environmental Law Review, 257.

${ }^{158}$ In addition to the EEA and the ETF; the agencies of the second wave are the following: the European Monitoring Centre for Drug Addiction (the "EMCDDA"), Regulation 302/93 of 8 February 1993, OJ L 36 of 12 February 1993, pp.1-8; the European Agency for the Evaluation of Medicinal Products (the "EMEA), Regulation 2309/93 of 22 July 1993, OJ L 214 of 24 August 1993, pp.1-21; the Office for Harmonisation in the Internal Market (the "OHIM"); Regulation 40/94 of 20 December 1993, OJ L 11 of 14 January 1994, pp.1-36; the European Agency for Health and Safety at Work (the "EU OSHA"), Regulation 2062/94 of 18 July 1994, OJ L 216 of 20 August 1994, pp.1-8; the Community Plant Variety Office (the "CVPO"), Regulation 2100/1994 of 27 July 1994, OJ L 227 of 1 September 1994, pp.1-30; the Translation Centre for Bodies of the European Union (the "CdT"), Regulation 2965/94 of 28 November 1994, OJ L 314 of 7 December 1994, pp.1-5. Two additional agencies were created in the late nineties, the European Monitoring Centre for Racism and Xenophobia (the "EUMC"), see Regulation 1035/97 of 2 June 1997, OJ L 151 of 10 June 1997, pp.1-7, and the European Agency for Reconstruction, (the "EAR"), Regulation 2454/99 of 15 November 1999, OJ L 299 of 20 November 1999, pp.1-8. The latter was instituted as a response to ad hoc circumstances, i.e. the management of the EC cooperation towards Kosovo in the post war period.
} 
aspects of EC policy (e.g. social policy, environmental security, intellectual property, etc.). ${ }^{159}$

At the beginning of this decade, several additional agencies were adopted at the EC level. This is the case of the European Food Safety Authority (EFSA), the European Maritime Safety Authority (EMSA) and the European Aviation Safety Authority (EASA). ${ }^{160}$ The adoption of these agencies could well constitute the beginning of a third wave of the "agencification" process. Indeed, the European Commission has recently put forward proposals for the creation of agencies in a variety of sectors. In the field of rail transport, the "European Railway Agency" is in the process of being formed (ERA). ${ }^{161}$ A noticeable feature of this third stage of agencification is that the agencies are in majority dealing with issues concerning safety and inter-operability.

Other ad hoc agencies might be set up in a near future. The Commission has proposed to establish a Community Fisheries Control Agency (the "CFCA") and a European Chemicals Agency (the "ECA"). ${ }^{162}$. In the information society sector, a Network and Information Security Agency (the "NISA") is currently being established. ${ }^{163}$ Finally, discussions over the setting up of a European Procurement Agency have also recently been reported. ${ }^{164}$

\section{Review of the institutional regulatory parameters}

The three institutional regulatory parameters examined above in the context of NRAs will also represent the conceptual framework of our analysis of the EAs.

\footnotetext{
159 See M. Everson, supra note 4 at p.194. Another distinguishing feature of this second wave of "agencification" is that these agencies were entrusted with data collection missions.

${ }^{160}$ The EFSA was established by Council Regulation No 178/2002 of 28 January 2002, OJ L 31 of 1 February 2002, pp.1-24. The EMSA was established by Council Regulation No 1406/2002 of 27 June 2002, OJ L 208 of 5 August 2002, pp.1-9. The EASA was established by Council Regulation No 1592/2002 of 15 July 2002, OJ L 240 of 7 September 2002, pp.1-20.

${ }^{161}$ The creation of a European Railway Agency (the "ERA") should be soon agreed upon by the Council and the Parliament. See Common Position 56/2003 of 26 June 2003 with a view to the adoption of a Regulation of the European Parliament and of the Council of establishing a European Railway Agency, OJ C 270 E/48 of 11 November 2003, pp.25-47. See also Proposal for a Regulation establishing a European Railway Agency, $\operatorname{COM}(2002) \quad 23$ final, available at http://europa.eu.int/comm/transport/rail/library/com23en.pdf

162 See respectively Communication from the Commission, "Towards Uniform and Effective Implementation of the Common Fisheries Policy”, 21 March 2003, COM(2003) 130 final and see Proposal for a Regulation concerning the Registration, Evaluation, Authorisation and Restriction of Chemicals establishing a European Chemicals Agency and amending directive 1999/45 and Regulation on Persistent Organic Pollutants, supra note 3.

${ }^{163}$ The Council of Ministers and the EP have reached an agreement on the proposal made by the Commission for the creation of the NISA. Observers consider that the agency will start its operations in the beginning of 2004. See Press release from the European Commission, IP/03/1577 20 November 2003. See also Proposal for a Regulation Establishing the European Network and Information Security Agency, 11 February 2003, COM(2003) 63 final. See also Commission Press Release 03/208, 10 February 2003.

${ }^{164}$ With regards to the European Procurement Agency, the project has not been formally adopted. It is still at the stage of discussions between MS. See European Report 2778 of 21 May 2003.
} 


\subsection{Decentralization vs. centralization}

As we have seen in Part II, one could argue that the EC institutions have too easily dismissed the benefits that would be brought by the creation of European regulatory agencies in sectors such as energy and telecommunications, which are characterized by substantial externalities, which should be internalized through centralized action. ${ }^{165}$ On the other hand, one could also argue that, in some cases, the EC institutions failed to make a sufficient case for creating European Agencies. In a system characterized by subsidiarity in the field of non-exclusive competences, the creation of an EA must be justified by the fact that (i) the matter in question cannot be satisfactorily addressed at the national level and (ii) the goals can be better achieved by action at the EC level (i.e. through the creation of a EA). To refer to the test used above, the presence of externalities or of regulatory economies of scale can be one factor justifying intervention at the EC level. ${ }^{166}$ Based on that test, it is not clear whether all the agencies created in the fields of non-exclusive competences would all pass the subsidiarity test. ${ }^{167}$

The EAs dealing with internal market issues, such as the OHIM, the EAMA or the CPVO would probably meet this test. This would also be the case for the EAs designed to tackle safety and inter-operability matters, such as the EASA, the EMSA or the proposed ERA, since again these matters have a clear trans-European component. But how about the European Monitoring Centre on Racism and Xenophobia, which has among its missions to develop strategies to combat racism and xenophobia? ${ }^{168}$ Is this a European or national matter? One could argue that the appropriate level to address these issues will in some cases be lower than the EC level (e.g. can we seriously compare the problems of racism which exist in France and in Austria) and in other cases higher than the EC level (e.g. anti-Semitism is a global problem). ${ }^{169}$ There does not seem to be many racism issues that have a specific EC-wide dimension. The same could be said with the European Monitoring Centre for Drugs and Drug Addiction. Once again, much would be gained to

\footnotetext{
${ }^{165}$ As seen above, the Green Paper on Services of General Interest has outlined the problem of the impact of national regulatory decisions on cross border transactions within the internal market. See Green Paper on Services of General Interest, supra note 41 at p.49.

${ }^{166}$ See R. Van den Bergh, supra note 9 at p.341.

${ }^{167}$ Various interpretations have been given of the concept of non exclusive competences. For a narrow interpretation, see A.G. Toth, supra note 7. For an extensive one, see Jo Steiner, "Subsidiarity under the Maastricht Treaty" in David. O'Keffe and Patrick M. Twomey (eds.), Legal Issues of the Maastricht Treaty, (1994, Ch.4, 57. If a proposed agency falls within a subject matter that is a non exclusive competence of the EC, it is then necessary to prove that (i) the goals to be achieved cannot satisfactorily be achieved by MS and that (ii) the goals can be better achieved by action at the EC level (i.e. through the creation of a EA). See P. Craig and G. de Búrca, supra note 30 at pp.116-117.

${ }^{168}$ See Council Regulation 1035/97 of 2 June 1997 establishing a European Monitoring Centre on Racism and Xenophobia, supra note 158.

${ }^{169}$ The Regulation's elliptic justification for the choice of the EC level supports this view. See recital 16 of the preamble of Regulation 1035/97, supra note 158: "Whereas racism and xenophobia are phenomena which manifest themselves at all levels within the Community: local, regional, national and Community, and therefore the information which is collected and analysed at Community level can also be useful to the MS authorities in formulating and applying measures at local, regional and national level in their own spheres of competence"
} 
undertake a serious analysis of the matters that need or do not need the creation of an institution at the EC level. ${ }^{170}$

In addition to this, the subsidiarity test implies compliance with the principle of proportionality. Article 5(3) of the Treaty requires that "Any action by the Community shall not go beyond what is necessary to achieve the objectives of this Treaty". Thus, even if action at the EC level is justified pursuant to the subsidiarity test that was examined above, there would still be some limits as to the form and the intensity of Community action. ${ }^{171}$ For instance, while action at the Community level against racism or drug addiction might be justified pursuant to Article 5(2) of the Treaty, such initiatives should remain proportionate pursuant to Article 5(3). It can therefore be questioned whether the creation of EAs in the field of racism or drugs complies does not go beyond what is strictly necessary. Indeed, one could argue that the creation of an agency is excessive in that it will involve substantial costs for a long period of time the establishment of institutions and that instead, a number of alternative means of action (such as, the adoption of substantive provisions in a directive or the adoption of guidelines or the creation of informal cooperation networks would be available).

\subsection{Homogeneity vs. diversity}

In Part II, we have seen that the NRAs show few features in common except that they have to comply with the requirements laid out in the liberalization directives and that they are all involved (sometimes in different ways) in economic regulation. There is some good reason to this, such as the existence of different legal and administrative traditions, as well as different policy approaches among the MS. In addition, the establishment of telecommunications, energy or rail regulators is a new phenomenon and there is a need for institutional experimentation.

Perhaps, more surprisingly, the institutional features of the EAs are equally disparate, although all these agencies have been created through a similar legal instrument (i.e., a Council Regulation) and are called to operate within a common jurisdictional order. ${ }^{172}$ The setting up of agencies does not seem to have followed a coherent administrative method. It has responded to ad hoc circumstances, instead of having been based upon a carefully reflected approach. ${ }^{173}$

\footnotetext{
${ }^{170}$ See R. Van den Bergh, supra note 9. The economic literature contains valid arguments against the centralization of certain policies.

${ }^{171}$ See P. Craig and G. de Búrca, supra note 30 at p. 117.

${ }^{172}$ The picture becomes even more disparate if one considers that the European Central Bank (ECB) is another form of agency. However, for the purpose of the present article, we do not include the European Central Bank (ECB) within the meaning of EAs. Indeed, the ECB has been granted official recognition within the Treaty (Article 8) and therefore presents features that are different to those of the other EAs. Nonetheless, we acknowledge that, to a certain extent, most of the remarks that will be made below might apply to the ECB. In this respect, several authors have included the ECB within the analysis of the general problematic of EC Agencies. See, in this respect, M. Everson, supra note 4 at p.187.

${ }^{173}$ See M. Everson, supra note 4 at p.184. In some cases, European agencies were created to respond to an urgent situation (such as the EAR, for the reconstruction of Kosovo, the EFSA following the BSE crisis and the EMSA following the growing concern for maritime safety after the 'Erika' disaster). In other cases, the Commission may have been tempted to propose the creation of agencies to reduce its workload and extend
} 
In this section, we first try to identify the common features of the agencies that we have identified above. We then show that, despite these common features, important differences exist between these agencies and we explore whether these agencies can be classified into distinct categories. We see that most authors try to classify these agencies by relying on functional categories, an approach which, however, creates more problems than it solves. We then see that the various policy documents published by the Commission on the issue of EAs contain contradictions and fail to offer a convincing framework on how to operate reforms on this issue. Finally, we propose our own classification of EAs and explore the various consequences of this classification.

\subsubsection{Common Features of the EAs}

Notwithstanding the important differences existing among these agencies and the variety of fields in which they are active, it is possible to identify seven common features. First, the five kinds of agency seen above have generally a limited mandate, which is laid down by the establishing regulations and consists of tasks of a technical, scientific and managerial nature. This is the case, for instance, of the OHIM which is entrusted with the duty of "implementing in relation to every trade mark the trade mark law created by Regulation 40/94". ${ }^{174}$ Thus, the agency is endowed with legal personality only to the extent of its mandate and therefore cannot act beyond it. ${ }^{175}$

Second, a majority of agencies (with the exception of the OHIM and the CVPO and to a certain extent the EMEA and the EASA) enjoy very limited powers. Most of them are generally entrusted with information and coordination tasks and are not competent to adopt binding decisions.

Third, all agencies operate under the authority of an executive director who is generally entrusted with the day to day administration of the agency, staff-related matters, and general preparation, implementation, budgetary and representation duties. ${ }^{176}$

Fourth, the agencies have an administrative or management board, the majority of whose members are representatives of the MS. The board lays down the general guidelines that the agency will follow in its actions, and adopts the work program of the agency. ${ }^{177}$

\footnotetext{
its sphere of influence through agencies on which it enjoys a power of control. Some MS may also have been tempted to support the creation of European agencies in order to bid for the possibility of having one of these agencies located in its territory.

${ }^{174}$ See preamble of Council Regulation 40/94 of 20 December 1993 on the Community Trade Mark of 20 December 1993, supra note 158.

${ }^{175} \mathrm{Id}$. at Article 111. This is also true for the other categories of agencies where explicitly limited mandates can be found. As far as the "observatory" model is concerned, the EEA's mandate is precisely identified and an exhaustive list of ten duties is provided by in Article 2 of Regulation 1210/90. Regarding the “cooperation" model, the Cedefop's duties are clearly defined at article 2 of Regulation 337/75. Finally, as far as the "executive" model is concerned, the CdT's mission is defined at article 2 of Regulation 2965/94.

${ }^{176}$ The directors may also have additional remits connected with the specific purpose of the agency (e.g., for the OHIM the President has competence to submit proposal for the amendment of the EC Trademark Regulation).
} 
Fifth, the agencies generally function through committees or are assisted by such structures. This is, for instance, the case of the EMEA, which is assisted by two committees, i.e. the Committee for Proprietary Medicinal Products and the Committee for Veterinary Medicinal Products. In such a case, the executive director is generally given the duty of coordinating the work of the committees. This is also the case of the EEA, which is assisted by a scientific committee which has to deliver an opinion (i) where provided for by the regulation and (ii) on any scientific matter concerning the agency's activity, which the management board or the executive director may submit to it.

Sixth, all the agencies are "decentralized". The concept of decentralization has a dual meaning. The first relates to the idea that the tasks of regulation are withdrawn from the centralized responsibility of the Commission. ${ }^{178}$ The second meaning of decentralization is that the EAs are located all over the territory of the EU. ${ }^{179}$ This latter feature, which results from the desire to reduce the concentration of the EC administration in Brussels, does not entail significant consequences with respect to their missions and powers. In contrast, it has important consequences for their creation and date of inception. In a majority of cases the constituent act of an agency does not make reference to the location of their headquarters. ${ }^{180}$ For this reason, Article 289 of the EC Treaty has been used to decide over the location of the agencies. This provision requires a consensus between the Heads of State. This has sometimes proven difficult. Indeed, MS tend to negotiate vigorously in order to attract agencies to their territories. ${ }^{181}$

Finally, a majority of the EAs so far created have a similar legal basis, i.e. Article 308 of the EC Treaty (sometimes combined with another Treaty provision). ${ }^{182}$ As has been previously observed, the EC Treaty does not provide a specific legal basis for the creation

\footnotetext{
${ }^{177}$ For the OHIM see Article 122 of Regulation 40/94, supra note 158; See Article 8 of Regulation 1210/90 for the EEA, supra note 157; See article 4 of Regulation 337/75 for the Cedefop, supra note 156; See Article 4 of Regulation 2965/94 for the CdT, supra note 158.

${ }^{178}$ See L. Grard, supra note 4.

179 This is explicable by political reasons. The decentralization of new institutions has been seen as an instrument to mitigate critics against the Brussels-based bureaucracy.

${ }^{180}$ See Communication from the Commission on the Operating Framework for the European Regulatory Agencies, supra note 18 at p.7.

${ }^{181}$ The difficulties to reach an agreement over the final location of an agency lead to important delays which, in turn, entail various costs. Indeed, until a location is agreed upon, the agency cannot recruit staff. It must therefore hire provisional staff and select a provisional location. Most of the time, the agency will provisionally be located in Brussels. This has, for instance, been the case of the EASA. See L. Grard, supra note 4 at p.4. It has recently been agreed at the European Council in Brussels on 13 December 2003, that the EASA would be located in Germany (Cologne). Also, Finland and Italy have agreed on the respective locations of the EFSA and of the proposed ECA after lengthy and difficult negotiations. The former will be located in Italy (Parma) and the latter will be located in Finland (Helsinki).

${ }^{182}$ See Paul Craig, "The Community Political Order", (2003) 1 Indiana Journal of Global Legal Studies, 131. The exceptions are the EEA (Article 175), as well as the more recent agencies i.e. the EFSA (Articles 37, 95, 133 and 152(4)b), the EASA (Article 80(2)), the EMSA (Article 80(2)), as well as the two proposed agencies, i.e. the NISC (Articles 95 and 156) and the ERA (Article 71(1)).
} 
of EAs. Thus, Article 308 has been used in order to create agencies at the EC level. ${ }^{183}$ The situation is, however, changing. The Commission increasingly introduces proposal for agencies based on specific Treaty provisions. For instance, in the field of transport, the legal basis for the creation of the EASA and the EMSA is Article 80(3) of the EC Treaty. This is confirmed in the Communication on the Operating Framework for the European Regulatory Agencies, where the Commission considers that "the legal instrument creating it [the agency] must be based on the provision of the Treaty which constitutes the specific legal basis for that policy". ${ }^{184}$ The rationale for this is twofold. ${ }^{185}$ A first reason is that relying on such specific legal basis implies majority voting, instead of the unanimity voting provided for by Article 308. Given the importance for the Commission to outsource some of its tasks, it tends to favour the lightest legislative procedures. A second reason lies in the fact that the substantive range of activities of the proposed agency will tend to be narrower in the case of a specific Treaty provision than in the case of Article 308 because in the latter case, the Council has a wide margin of discretion over the nature of the Community action to adopt. ${ }^{186}$ This aspect has its importance in light of the Commission's reluctance to create EAs enjoying a wide range of powers. ${ }^{187}$

\subsubsection{The different types of EAs - functional typology}

Although EAs share the above characteristics, they also differ in many ways. Most of the scholars who tried to classify these agencies relied on a functional typology. According to such a typology, five types of EAs can be identified according to the duties entrusted to them.

First are the agencies that are entrusted with the implementation of EC regimes in a variety of fields. These agencies have generally been created in order to serve the operation of the internal market in highly specialized areas. This is, for instance, the case of the Office for Harmonisation in the Internal Market (the "OHIM"), the Community Plant Variety Office (the "CPVO"), the European Agency for the Evaluation of

\footnotetext{
${ }^{183}$ The formulation, as well as the interpretation of Article 308, has proved very flexible. See Joseph H.H. Weiler, "The Transformation of Europe", (1991) 100 Yale Law Journal, 2403. See also P. Craig and G. de Búrca, supra note 30 at pp.105-107.

${ }^{184}$ See Communication on the Operating Framework for the European Regulatory Agencies, supra note 18 at $\S 4.1$.

${ }^{185}$ The Commission argues that it should be so "Since the regulatory agency is an instrument of implementation of a specific Community policy". See Id. While this may be true in terms of legal consistency, we argue that there are two other main reasons for this.

${ }^{186}$ See K. Lenaerts, supra note 4 at p.43.

${ }^{187}$ See infra at 2.2.3. It could be observed that these two reasons are, to a certain extent, contradictory. On the contrary, we consider that they are easily reconcilable in light of the Commission ambivalence towards EAs. The Commission supports the creation of EAs for reasons linked to administrative congestion and self-administration. While doing so, the Commission is, however, not ready to transfer large portions of its authority to the EAs. The choice of a specific Treaty provision as the legal basis for EAs is thus interesting for the Commission for it facilitates the creation of EAs while ensuring that both their mandate and powers are precisely circumscribed. At any rate, this new trend shall be welcomed since it will most probably strengthen the influence of the EP (especially with regards to internal market matters), which was merely consulted pursuant to Article 308.
} 
Medicinal Products (the "EMEA") and the proposed European Chemicals Agency (the "ECA"). ${ }^{188}$ In order to understand the functioning of these agencies, one can refer to the example of the OHIM. In the early 1990s, it was felt that the completion of the internal market was facing important obstacles deriving from the existence of different national intellectual property regimes and various registration procedures. As IP rights confer national protection according to the territoriality principle, they could thus have impeded the free movement of goods. In order to avoid this risk of market fragmentation, the OHIM was set up with the mission of deciding on applications for the grant of the EC Trade Mark and to rule on other issues in this field. This form of agency, closely connected with the completion of the internal market and entrusted with quasi-judicial powers is also referred to as the regulatory model.

The second group of agency is composed of entities entrusted with an observatory role. This is the case of the European Environment Agency (the "EEA"), the European Monitoring Centre for Drug and Drug Addiction (the "EMCDDA"), the European Monitoring Centre on Racism and Xenophobia (the "EUMC"), and possibly the European Food Safety Agency (the "EFSA"). ${ }^{189}$ These agencies have the duty to collect, process and diffuse reliable information. Although operating in different fields, the procedures organizing the collection of information, the working methods as well as the powers granted to these agencies are very similar. A salient feature of these agencies relates to the fact that they generally have to coordinate networks of experts. ${ }^{190}$ These experts may be representatives from the MS, but may also belong to non EC-institutions or sometimes to international organizations.

The third category of agency is commonly referred to as the cooperation model. It includes the two first-generation agencies, i.e., the European Centre for the Development of Vocational Training (the "Cedefop") and the European Foundation for the Improvement of Living and Working Conditions (the "EUROFOUND"), as well as the European Agency for Safety and Health at Work (the "EU-OSHA"). ${ }^{191}$ The goal of these agencies is to promote social dialogue at the European level. In the field of professional training, for instance, the Cedefop serves as a forum for discussion and exchange of experiences among social and political actors. A significant feature of these agencies

\footnotetext{
${ }^{188}$ See Council Regulation 40/94 of 20 December 1993 establishing the OHIM supra note 158. See Council Regulation 2100/94 of 27 July 1994, establishing the CPVO, supra note 158. See Council Regulation 2309/93 of 22 July 1993 establishing a EMEA supra note 158.

189 See Council Regulation 1210/90 of 7 May 1990 establishing a European Environmental Agency amended by Council Regulation 933/1999 of 29 April 1999, supra note 157. See Council Regulation 302/93 of 8 February 1993 establishing a European Monitoring Centre for Drugs and Drug Addiction, supra note 158. See finally Council Regulation 1035/97 of 2 June 1997 establishing a European Monitoring Centre on Racism and Xenophobia, supra note 158.

190 These networks are the European Environment Information and Observation Network ("EIONET") for the EEA, the European Information Network on Drugs and Drug Addiction ("REITOX") for the EMCDDA and the European Racism and Xenophobia Network ("RAXEN") for the EUMC.

191 See Council Regulation 337/75 of 10 February 1975 establishing the European Centre for the Development of Vocational Training, supra note 156. See Council Regulation 1365/75 of 26 May 1975 establishing the European Foundation for the Improvement of Living and Working Conditions, supra note 156. See Council Regulation 2062/94 of 18 July 1994, establishing a European Agency for Safety and Health at Work, supra note 158.
} 
relates to their management structure. They are operated by a tripartite management board representing social partners (employers and labor) and representatives from the MS and the European Commission.

The fourth category is composed of agencies that are operating as subcontractors to the European public service and are thus entrusted by the Commission with limited non discretionary powers for the management of Community programmes. They are generally referred to as the executive model as they have been instituted in order to perform purely technical tasks. These agencies provide administrative support to the Commission which explains why they are sometimes considered as mere additional specialized units of some of the Commission's DGs. ${ }^{192}$ This category comprises the European Agency for Reconstruction (the "EAR"), the European Training Foundation (the "ETF"), and the Translation Centre for the Bodies of the EU (the "CdT"). ${ }^{193}$ These agencies are active in very different fields. The EAR is in charge of the management of the European Aid programs for the rebuilding of Kosovo. The ETF has the duty to support the reforms in the field of professional training in the Partner countries to the EC (MEDA, ACP and other countries). Finally, the CdT was set up to respond to the translation needs of the EC institutions and other public bodies. By contrast with the two first agencies, the latter is involved in more technical and administrative duties. The legal regime applicable to these agencies has recently been codified in a transversal regulation "laying down the stature of executive agencies to be entrusted with certain tasks in the management of Community programmes". ${ }^{194}$ This is an important achievement because it is the first binding EC transversal text that deals with the issue of agencies. However, these agencies are not regulatory entities. This has been confirmed in the Communication on the Operating Framework for the European Regulatory Agencies. ${ }^{195}$

The fifth type of agencies constitutes the yet to be implemented network safety/interoperability model. It is composed of agencies that are entrusted with two sets of missions. They have been assigned the duty to ensure safety in the operation of economic activities. This is, for instance, the case of the European Maritime Safety Agency (the "EMSA"), the European Aviation Safety Agency (the "EASA") as well as of the proposed Network and Information Security Agency (the "NISA") and to some extent of the proposed

\footnotetext{
${ }^{192}$ For an analysis of these agencies, see P. Craig, supra note 4, at p.13. Subsequent to the fall of the Santer Commission and to the fraud allegations directed at the Commission, the necessity for the later to focus on key policy issues became a priority. Thus, the possibility of externalizing the administration of some programmes for which it had the responsibility was strengthened. Externalization may also be carried out vertically, i.e. the Commission externalizing some of its programmes to network of national bodies. See P. Craig at p.19.

193 See Council Regulation 2454/99 of 15 November 1999 establishing a European Agency for Reconstruction, supra note 158. See Council Regulation 1360/90 of 7 May 1990, establishing a European Training Foundation, supra note 157. See Council Regulation 2965/94 of 28 November 1994, establishing a Translation Centre for the Bodies of the European Union, supra note 158.

${ }^{194}$ See Council Regulation 58/2003 of 19 December 2002, OJ L 11 of 16 January 2003, pp.1-8. Pursuant to this text, the powers of the subcontracting agencies are quite limited. See recital 5, Article 2 and Article 3 of the Regulation.

${ }^{195}$ See Communication from the Commission on the Operating Framework for the European Regulatory Agencies, supra note 18 .
} 
European Railway Agency (the "ERA"). ${ }^{196}$ Second, some of these agencies are also mandated to promote inter-operability as a way to facilitate the completion of the internal market. This is particularly true for the proposed ERA and to a lesser extent for the EASA. It must be stressed that there exists great diversity with respect to the powers conferred on these agencies. While the EASA seems to enjoy very broad powers (inspections, adoption of binding certification decisions, agreement power etc.), the EMSA and the EFSA have not been entrusted with comparable prerogatives (they have mainly advisory powers). ${ }^{197}$

Although such a functional typology is helpful from an analytical viewpoint, it cannot be the basis on which to propose reforms on the status of EAs. First, the typology is not tight proof as some of the EAs can fall within two or more of the categories described above. This is, for instance, the case of the EASA or of the proposed NISA, which could also belong to the implementation category as they are in charge of monitoring the implementation of the EC legislation in the field of air transport and information security. Similarly, the EMSA could be classified in the cooperation category in that it functions on the basis of collaboration between MS experts and the EFSA could be classified in the regulatory model in that it shows analogies with the functioning of the EMSA. ${ }^{198}$ Second, this typology contains too many categories to be used as a basis for reforms. Indeed, one cannot expect EC institutions to adopt five different regimes on the basis of these categories. To be given legal consequences, we believe a simpler categorization should be relied upon. As will be seen hereafter, the Commission seems to divide agencies in two categories, the "executive" agencies and the "regulatory" agencies.

\subsubsection{The Communication of the Commission on a framework for regulatory agencies}

Over the last ten years, the issue of the creation of EAs has been dealt with in several Commission documents within the general context of the Commission's debate on European Governance. The purpose of this debate was, inter alia, to improve the way rules and policy are applied in the European Union (the "EU").

First, the Commission published a White Paper on Governance in which it detailed several conditions for the setting up of agencies. According to the Commission, agencies:

- "can adopt individual decisions in specific areas but cannot adopt general regulatory measures";

- "cannot be given responsibilities for which the Treaty has conferred a direct power of decision on the Commission; and

\footnotetext{
${ }^{196}$ See supra at notes 160,161 and 163 .

${ }^{197}$ For a comparative analysis of the powers of the EASA and of the EMSA, see L. Grard, supra note 4. This author points out the important differences existing between the EASA and the EMSA despite the fact that both are entrusted with technical regulation duties in the field of transport.

${ }^{198}$ These analogies have been pointed out by E. Vos, supra note 4 at p.1132.
} 
- cannot be granted decision making powers "in areas in which they would have to arbitrate between conflicting public interests, exercise political discretion or carry out complex economic assessments". 199

The conditions placed by the Commission on the creation of EAs appear particularly restrictive and would certainly prevent the creation of fully-fledged regulatory agencies as was envisaged in Part II. The Commission decided to put the issue on its agenda and committed itself to defining, by 2002, the criteria for the creation of new regulatory agencies and the framework within which they should operate.

In the line traced by the White Paper, a second step was reached with the adoption of a Communication entitled "Better Law Making" where the Commission revealed that it had the intention of submitting to the EP and to the Council the terms of an inter-institutional agreement setting out the conditions for the formation of such agencies. ${ }^{200}$

In December 2002, the Commission defined its views on the content of such interinstitutional agreement with the adoption of a Communication on the Operating Framework for the European Regulatory Agencies. ${ }^{201}$ In substance, the Commission draws a distinction between two categories of agencies. The first category comprises the "executive" agencies, which are defined as those responsible for purely managerial tasks, i.e. to assist the Commission in implementing the Community's financial support programmes. They are characterized by their limited autonomy and are governed by Regulation 58/2003. ${ }^{202}$ An example of such agencies can be found in the European Agency for Reconstruction which has been entrusted with the management of European aid towards Kosovo. The second category comprises the "regulatory" agencies, which are defined as those "required to be actively involved in exercising the executive function by enacting instruments which contribute to regulating a specific sector". ${ }^{203}$ Within this category of regulatory agencies, the Commission proposes to make a further distinction between the "decision-making" agencies, i.e. those empowered to enact legal instruments binding on third parties, and the "executive" agencies, i.e. those who have no independent power of decision vis-à-vis third parties but perform all other regulatory tasks. Considering that in the categorization outlined above, the Commission distinguished between "executive" agencies and "regulatory" agencies, it is simply absurd that within the second category it re-introduces a distinction between "decision-making" agencies and "executive" agencies. An "executive" agency sounds nothing else than a contradiction in terminis.

In its Communication, the Commission also provide for a list of conditions for the creation of EAs. These conditions largely follow the restrictive approach it adopted in the White Paper on Governance. For several reasons, we are not convinced by the policy

\footnotetext{
${ }^{199}$ See White Paper on European Governance, supra note 16 at p.24.

${ }^{200}$ See Communication from the Commission, "Better Law Making", supra note 19 at p.5

201 See Communication from the Commission on an Operating Framework for European Regulatory Agencies, supra note 18 .

${ }^{202}$ Id. at p.3. See also Regulation 58/2003, supra note 194.

${ }^{203}$ Id. at p.4.
} 
approach proposed by the Commission in the area of EAs. First, as we have seen above, the typology used by the Commission lacks analytical rigour and it is to be feared that it will lead to more, rather than less, confusion. Symptomatic of this fact is that in its Communication on the Operating Framework for the European Regulatory Agencies, the Commission does not even try to classify existing agencies under its proposed categorization. In its White Paper on European Governance, the Commission just mentioned that among the existing agencies, three only could be considered as being "regulatory", but it does not explain why this is the case. ${ }^{204}$ More recent documents also tend to suggest that the Commission itself is not clear with its own terminology. For instance, in the Green Paper on Services of General Interest, the Commission takes the view that the proposed ERA cannot be considered as a regulatory agency while the criteria laid down in the Communication on the Operating Framework for the European Regulatory Agencies would lead to a different conclusion. Pursuant to the Communication, the ERA would fall under the concept of regulatory agencies but would belong to the "executive" subcategory that has just been described. Second, because of its restrictive interpretation of the Meroni doctrine, the Commission fails to create a category, which could be used to accommodate the European telecommunications or energy regulatory agencies the creation of which we proposed in Part II. Under its proposed categorization, these agencies are not even considered by the Commission.

\subsubsection{Our proposed classification}

In order to clarify and add analytical rigour to the debate, we propose our own classification of EAs, which no longer relies on functional approach, but on a legal criterion, i.e. the intensity of the prerogatives entrusted to the agencies for carrying out their missions. Pursuant to this criterion, three categories of EAs can be identified. The first category refers to the "executive" agencies, which would comprise all European agencies that are responsible for (i) purely managerial tasks (e.g., the EAR, the ETF and the CdT), or (ii) observatory roles (the EEA, the EMCDDA, and the EUMC), or (iii) missions of cooperation (e.g., the Cedefop, the Eurofound or the EU-OSHA). The common feature between these agencies is that they would have no decision-making power, all relevant decisions being taken by the European Commission. The Commission already refers to the category of executive agencies for the bodies in charge of managerial tasks such as the EAR, but we propose to add two additional categories of agencies (according to a functional typology), which have no decision-making powers of decision either.

The second category would refer to the "decision making" agencies, which would comprise all agencies that have the power to enact legal instruments binding on third parties (e.g. the OHIM, the CVPO, the EASA) or of the agencies that without enjoying a formal decision-making power, in fact enjoy a considerable influence over the adoption of final decisions by the Commission (e.g. the EMEA and possibly the EFSA and the

\footnotetext{
204 i.e., The OHIM, the CPVO and the EMEA. See White Paper on European Governance, supra note 16 at p.24.
} 
EMSA). ${ }^{205}$. This category is being relied upon by the Commission in its Communication on the Operating Framework for the European Regulatory Agencies as a subcategory of the category entitled "regulatory" agencies. We believe, however, that the interpretation of the concept of regulatory agencies given by the Commission is misleading as this concept is generally used among experts and in most jurisdictions to designate agencies, which have discretionary powers in translating political choices into action. This is, for example, the case of the NRAs, which, as we have seen in Part II, have wide discretionary powers to translate the national legislation implementing the liberalization directives (e.g., political acts adopted by the national parliaments), into action (e.g., through decisions, orders, regulations, etc.). From a terminological view point, it would be totally inconsequent to call European Regulatory Agencies, bodies which do not resemble in any way to the National Regulatory bodies, a concept expressly referred to in the liberalization directives.

Our third category would thus refer to true "regulatory" agencies, which would comprise all European agencies that enjoy the types of powers enjoyed by the NRAs, including a discretionary power to translate broad legislation guidelines into concrete instruments. Of course, such category could not be created under the current restrictive interpretation laid down in Meroni. As indicated in Part II, the creation of such a category of agencies would require either an over-ruling of Meroni by the ECJ or a modification of the Treaty. Although we are very much in favour of this evolution, several years may pass before it takes place. In the meantime, we prefer that the Commission refrain from calling regulatory agencies bodies that do not share the characteristics that are generally associated with regulatory agencies, such as the NRAs or equivalent bodies elsewhere in the world.

Once a classification has been proposed, the next relevant question is to determine the legal consequences, which will be attached to it. In adopting Regulation 58/2003, the Council has already addressed most of the relevant issues regarding the "executive" agencies. This regulation deals with the creation and winding up of executive agencies, their legal status and the choice of their location, their tasks, their structures, their organs of governance, and their budget. An important question is whether comparable regulations should be adopted for the other categories proposed, i.e. the decision-making agencies and the regulatory-agencies. In fact, at this stage, there is no need for a regulation dealing with our category called regulatory agencies since the creation of such agencies would require an over-ruling of the Meroni doctrine by the ECJ or a Treaty amendment. The question we thus face is whether we would need to adopt a second regulation dealing with the decision-making agencies. The main advantage of responding positively to this question would be that adopting a second regulation would be easy. Indeed, the Commission is itself proposing to adopt an instrument that would address the

\footnotetext{
${ }^{205}$ Indeed, the existence of a mere advisory power does not prevent EAs from enjoying a certain level of authority. The adoption of a non-binding decision (e.g. a recommendation) may well have a considerable impact and, in some circumstances, a similar effect as would a binding-one. This will be the case if the agency recommendation is respected and followed by stakeholders, or is taken as a binding basis for the adoption of a decision by the Commission. See Report of the French Council of State at p.378, supra note 20. See also R. Dehousse, supra note 4 at p.13. This hypothesis is known under the name of "sunshine regulation". See finally, R. Baldwin and M. Cave, supra note 47 at p.164.
} 
issues raised by regulatory agencies a concept we prefer to reserve to the yet-to-becreated bodies enjoying discretionary powers, but which by and large cover our proposed category of decision-making agencies.

Another approach would be to expand Regulation 58/2003 to our proposed category of decision-making authorities, which would then deal with both executive and decisionmaking agencies. As these categories of agencies differ on a number of key issues, this regulation would have to be characterised by a high degree of flexibility, which should not, however, translate in the lowest common denominator. Instead, the regulation should provide a series of core obligations that would be applicable to both categories of agencies, but also varying requirements depending on the category of agency concerned. For the sake of clarity, we believe that this latter approach is preferable as all procedural and other issues regarding EAs, would be addressed in a single piece of legislation, which we would propose to refer to as the European Agencies Procedural Regulation (EAPR).

Another important issue is whether this EAPR should only address the organizational matters tackled by Regulation 58/2003 (i.e. conditions for creation, legal status, location, tasks, etc.) or a broader set of issues, including the principles of good governance discussed in the next section. Here again, we believe that an integrated approach would be desirable even if the text has to provide varying requirements depending on the type of issue concerned.

\subsection{Principles of good governance}

In this section, we seek to determine whether the principles of good governance as described in Part II, are generally complied with by the EAs. We also propose measures that could be adopted to ensure better compliance of the EAs with these principles. We address good governance requirements in general, although in some places we indicate that variations might be needed to cater for differences between the different categories of agencies.

\subsubsection{Independence}

Independence of the agencies is perhaps the most central principle of good governance. ${ }^{206}$ Independence is generally understood as the absence of pressures from political and industry interests. ${ }^{207}$ It is not an abstract principle. Its implementation requires the adoption of a series of measures that will shelter the agency against undue pressures.

\footnotetext{
${ }^{206}$ Yet, it is not sure that all kinds of EAs need to be independent. For instance, this is probably not the case of the purely executive agencies. In addition, the optimal degree of independence shall certainly be different from one category of EA to another. For instance, it is possible that the EAs classified under the cooperation model need not as much independence (as they are fora for MS, EC institutions and stakeholders) as the agencies belonging to the observatory model (because they must issue reliable and objective information), the implementation model or the network safety/interoperability model. For a formulation of this idea, see M. Everson, supra note 4 at p. 185 .

${ }^{207}$ In this respect, independence prevents the risk of capture of the regulator. This involves two elements. First is an arm's length relationship with regulated firms, consumers, and other private interests. Second is an arm's length relationship with political authorities, i.e. the Commission, the Council and the EP. See
} 
A first set of measures relate to the appointment of the management of the agencies. ${ }^{208}$ With some limited exceptions, the Commission generally does not enjoy the power to appoint executive directors. ${ }^{209}$ It is only entrusted with the power to propose candidates, the appointment of the director being generally a prerogative of the management board of the agencies. Moreover, this power has recently been reduced with (i) the insertion of professional criteria in the regulations setting up new agencies and with (ii) the implementation of public calls for candidates in some cases. This should provide guarantees that the appointment of candidates is not biased (or at least perceived as such) in favour of the Commission. Nevertheless, the Commission is currently trying to regain influence in the appointment process. In its Communication on the Operating Framework for the European Regulatory Agencies, the Commission proposes that appointing powers be entrusted to it for the agencies that enjoy decision-making powers. ${ }^{210}$ This proposal runs counter to the independence of the EAs and can only be understood as an attempt by the Commission to maintain an influence on such EAs. An alternative approach whereby the Commission would propose names of candidates selected on the basis of objective criteria, which would subsequently be ratified by the European Parliament would be much preferable.

Second, it is subject to question whether the agencies are sufficiently independent vis-àvis the MS. Here again, we believe it is not the case. Indeed, most of the members of the EAs' management board are MS representatives. ${ }^{211}$ It therefore cannot be precluded that considerations linked with national interests may sometimes be taken into account within the decision-making process. This situation has been explicitly recognized by the Communication on the Operating Framework for the European Regulatory Agencies in which the Commission considers that the national representation principle insufficiently takes into consideration the Community interest. In addition, the application of the rule may be problematic in the larger context of enlargement. Thus, the Commission proposes that the board be limited to fifteen members, six being appointed by the Council, six by the Commission and three by interested parties (stakeholders etc.). ${ }^{212}$

\footnotetext{
George Stigler, "The Theory of Economic Regulation", (1971) 2 Bell Journal of Economics and Management Science, 3. On the theoretical ground, the idea of removing agencies from politics is enclosed in the very concept of regulation. Given that the purpose of regulation is micro-economic efficiency and that it does not seek to achieve redistributive goals, the consequence is that regulation should not be subject to majoritarian redistributive pressure exerted by majoritarian institutions i.e. political ones. Rather, regulation shall be entrusted to experts. See on this, M. Everson, supra note 4 and G. Majone, supra note 4. ${ }^{208}$ See W. Smith, supra note 22.

${ }^{209}$ The exceptions are the two fist generation agencies, i.e. the CEDEFOP and the EUROFOUND.

${ }^{210}$ In contrast, the Communication proposes that, for the agencies that are entrusted with executive duties, the procedure be reversed, i.e. the Commission proposes candidates to the Administrative Board which appoints the Director. See Communication from the Commission on the Operating Framework for European Regulatory Agencies, supra note 18 at p.10.

211 Dehousse observes that there is an evolution on this point. Recent proposals suggest that the administrative boards of future agencies might not include representatives of the MS. See R. Dehousse, supra note 4

${ }^{212}$ See Communication from the Commission on the Operating Framework for the European Regulatory Agencies, supra note 18 at p.9.
} 
Third, the constituent regulations do not generally provide for rules designed to prevent the so-called "revolving doors" practices. ${ }^{213}$ Members of the agencies are merely required to comply with a confidentiality obligation over professional secrets. ${ }^{214}$ By contrast, nothing prevents these members to join right away (i.e. without a "cooling off" period) industries they have been called to oversee or to interact with, once their term is over.

Finally, since agencies are established pursuant to legislative procedures and are not so to speak, "Treaty-Framed", they remain exposed to a possible amendment of their status. The EC legislative institutions can therefore, at any time, limit the attributions of the agencies and could even decide to dismantle them. This could well be used in order to exercise influence over the agencies.

\subsubsection{Lack of accountability}

The existing measures designed to ensure that EAs are accountable appear to be insufficient. This observation may be difficult to reconcile with the previous observation that they should be more independent. Indeed, it is sometimes considered that accountability and independence are conflicting concepts. ${ }^{215}$ As pointed out above, we believe, however, that independence and accountability can and must be combined. The control exercised by public representative institutions may indeed result in greater legitimacy for the agencies. This may in turn enhance their independence and remove them from political pressures. ${ }^{216}$ The inadequacy of the mechanisms designed to ensure that the EAs are accountable is discussed hereafter.

\section{Judicial Accountability}

In the EC legal order, the principal mechanism for ensuring judicial accountability of EAs takes the form of a review of the legality of their acts. ${ }^{217}$ The situation is here again extremely disparate. While some constituent regulations explicitly provide that the acts taken by the agencies are challengeable before the ECJ on the basis of Article 230 of the EC Treaty (annulment proceedings), other constituent regulations entrust the Commission

\footnotetext{
${ }^{213}$ See for instance Article 18 of the Regulation establishing the EUROFOUND.

${ }^{214}$ For an illustration of the dangers of such practices, see "Ethics Scandals Show Pentagon-Industry Ties are Still Problematic", 18 December 2003, Wall Street Journal Europe at pp.1 and 10.

${ }^{215}$ See X. Yatanagas, supra note 4 at p.40. See also M. Everson, supra note 4 at p.183 speaking of a "dilemma for any lawyer concerned with the institutional design of independent agencies".

${ }^{216}$ In practice, the experience of the US Federal Agencies and of the French IAAs supports this view.

${ }^{217}$ The question of the non-contractual liability of the EAs will not be examined here for two reasons. First, liability actions for regulatory actions seem extremely improbable given the restrictive conditions for the application of Article 288 imposed in the EC case law. Second, for reasons of public policy it is (as will be observed below) subject to question whether regulatory institutions should, in addition, be held liable for the acts they take, since they are called upon to perform delicate technical, risk and/or economic assessments. An action is currently pending before the Court of Justice involving an operator claiming damages for a Commission's negative clearance decision in a merger case (see Decision of the Commission Airtours/First Choice, IV/M.1524, supra note 52). It is thus too early to take a position on this issue. It will be finally noted that the solution may be different for the executive agencies. See in this respect the comments by P. Craig, supra note 4 at p.18.
} 
or a specific agency chamber with the review of the legality of the EAs' decisions. ${ }^{218}$ In other cases, the constituent regulations do not even provide for the possibility of judicial review. In the latter hypothesis, the classic rules governing the annulment action shall be applied (Article 230 of the EC Treaty) ${ }^{219}$ Reliance on this Treaty provision raises several problems. First, the acts of the EAs are not mentioned within the scope of the acts reviewable pursuant to Article 230 of the EC Treaty. ${ }^{220}$ This problem, however, does not appear insurmountable given the ECJ's broad interpretation of the acts reviewable under Article 230. In Les Verts and in Court of Auditors, ${ }^{221}$ the Court took the view that the EC is founded on the rule of law and that, as a consequence, all acts adopted by the EC "institutions" may be reviewed by the Court. ${ }^{222}$ In addition, the rules governing locus standi are not satisfactory. Individuals must prove that they are individually affected and directly concerned. ${ }^{223}$ This condition is extremely difficult to fulfil when acts concern a wide category of individuals, which may often be the case in the field of regulation. Categories of individuals affected by an act adopted by an EA may thus be left without any possibility of recourse.

As a matter of public policy it could, however, be questioned whether acts of the EAs should be subject to judicial review. ${ }^{224}$ It could, for instance, be argued that lengthy judicial review of regulatory acts might deprive these acts of most of their efficiency. This is, for instance, a serious problem in the US where the rulings of the federal agencies often give rise to lengthy litigation. In addition, it could be considered that courts of law are ill-equipped for evaluating technical and economic regulatory acts. While these arguments raise interesting issues, they do not appear decisive. These arguments are unconvincing. First, it is of utmost importance that a judicial review of procedural issues be available to operators. ${ }^{225}$ Second, with regards to substantive issues, judicial review should follow the standards provided for by administrative law. ${ }^{226}$ On the one hand, entities enjoying decision-making powers and a wide margin of appreciation should be submitted to a limited substantial control, i.e. whether there has been a serious and

\footnotetext{
${ }^{218}$ In the latter case, there is a subsequent possibility of filing an annulment action before the ECJ (in this case against the Commission's decision or against the agency's panel judgment). See Final Report of the Discussion Circle on the Court of Justice, 25 March 2003, CONV636/03, p.8. As far as executive agencies are concerned, the option followed is generally an administrative appeal before the Commission and the later possibility of filing an infringement action. This is provided for by the Framework Regulation 58/2003 at Article 22(1), supra note 194. See, on this, P. Craig, supra note 4 at p.16. In contrast, internal review by a specific chamber within the agency has generally been chosen for these agencies that have been entrusted with decision-making powers (i.e., the OHIM, the CVPO and the EASA). The proposed ECA should also follow this model.

219 This is the case with respect to the EMSA, supra note 160.

${ }^{220}$ See P. Craig at p. 15 and K. Lenaerts at p.45, supra note 4.

${ }^{221}$ See ECJ, 23 April 1986, Les Verts vs. Parliament, supra note 63 and ECJ, 11 May 1989, Maurissen vs. Court of Auditors, 193-4/87, ECR 1989, p.1045.

${ }^{222}$ See P. Craig at p. 15 and K. Lenaerts at p.46, supra note 4.

${ }^{223}$ See ECJ 15 July 1963, Plaumann vs. Commission, 25/62, ECR 1963, p.95.

${ }^{224}$ See, on this, R. Baldwin and M. Cave, supra note 47 at p.302.

${ }^{225}$ For a formulation of this idea, see M. Everson supra note 4 at p.191.

${ }^{226}$ In the field of economic regulation, these standards of review have been endorsed by the ECJ and the CFI. However, it should be noted that in the field of competition law the CFI has recently shown that it was ready to perform in depth analysis of the Commission's decisions. See for instance, the Babyliss case, CFI 3 April 2003, Babyliss SA vs. Commission, T-114/02.
} 
manifest breach of law. On the other hand, entities enjoying a more limited margin of appreciation should be subject to an extended substantive control (i.e. a control of proportionality). ${ }^{227}$

At any rate, there is scope for an improvement of the rules governing judicial review of the EAs. ${ }^{228}$ The explicit provision in the constituent regulations of some agencies for mechanisms of judicial review constitutes a noticeable improvement with regards to legal certainty. ${ }^{229}$ There remain, however, a few questions. One is whether recourse to independent internal chambers should be preferred to an administrative appeal before the Commission. We believe that the former system is preferable as the latter gives the Commission undue influence on the regulatory processes. Another question is whether recourse to independent internal chambers should be preferred to direct appeal to the CFI. Here again, the former option is preferable in that the independent internal chamber's review may play a role of filter against unfounded appeals. This is important in light of the growing congestion of the CFI. Moreover, it does not rule out the possibility of judicial review as the CFI's jurisdiction over the decisions of the independent chambers would, in any event, remain.

\section{Financial Accountability}

As far as financial accountability is concerned, EAs are submitted to several controls. A first mechanism is the voting of the EP on the resources of the agencies. As many agencies depend ultimately on Community funds, the budgetary power enjoyed by the EP on expenditures is rather important. The EP could well use such power so as to push the agencies towards more transparency and to increase parliamentary scrutiny of their activities. However, this has not happened in practice and the analysis of the evolution of budgetary procedures does not support this argument. Second, a control is exercised by the Court of Auditors by virtue of Article 248 of the EC Treaty. ${ }^{230}$ The Court's main duty is to determine whether the annual accounts are "reliable" and the transactions "legal and regular" (see Article 248(1) al.2 of the EC Treaty). ${ }^{231}$ However, this control has a limited preventive value since the reports are issued by the Court of auditors more than one year after the operations have been made. ${ }^{232}$

The financial control of the EAs is thus limited in that it only takes place on an ex post annual basis. Major improvements could, however, be made with the adoption of a

\footnotetext{
${ }^{227}$ This is in line with the standards used by the ECJ in the field of competition law. See P. Nicolaides, A. Geveke and A.M. den Teuling, supra note 4 at p. 21 .

${ }^{228}$ See Communication from the Commission on the Operating Framework for the European Regulatory Agencies, supra note 18 at p.13.

${ }^{229}$ See K. Lenaerts, supra note 4 at p.46.

${ }^{230}$ See Jan Inghelram, "The European Court of Auditors: Current Legal Issues", (2000) 37 Common Market Law Review, 129; Brigid Laffan, "Becoming a 'living institution': the Evolution of the European Court of Auditors", (1999) 2 Journal of Common Market Studies, 251.

${ }^{231}$ The Court must provide the Council and the EP with a 'statement of assurance' as to the "reliability of the accounts and the legality and regularity of the underlying transactions".

${ }^{232}$ The main instrument of the Court of auditors is the adoption of a yearly general report that reports the results of the budgetary review. In addition to this, the Court has the possibility to adopt special reports on specific subject matters. Finally, it can also deliver opinions on request from another institution.
} 
budgetary mechanism similar to the executive oversight function carried out by the Office of Management and Budget (the "OMB") in the US. ${ }^{233}$ This body is directly connected to the US Presidency and, inter alia, prepares the budget of the various administrative bodies, controls their implementation and reviews their expenditures and purchasing policies on a permanent basis. This gives considerable incentives for diligent management. The evolution in EC legislation is, however, encouraging. EAs are increasingly submitted to the control of the European Anti-Fraud Office (OLAF) and to the financial controller of the Commission. ${ }^{234}$

\section{Political Accountability}

The importance of accountability before representative institutions is widely acknowledged. ${ }^{235}$ However, few constituent regulations provide for obligations of regular reporting before the EP. ${ }^{236}$ The absence of such a mechanism has been heavily criticized in the context of the Treaty-framed European Central Bank. ${ }^{237}$ This criticism should be applied to EAs as well. The submission of entities to the scrutiny of parliamentary committees may prove useful as it may oblige the agencies to provide reasoned explanations of their initiatives. This may result in an overall improvement of the decision-making process.

Another aspect of accountability is linked to the public. Seen from that standpoint, the accountability of EAs is also insufficient. In most instances, the constituent regulations only require the publication and presentation of an annual report of activities. In contrast with most agencies in the US and in other countries, EAs are under no obligation to publish explanatory documents, issue regular reports or organize public consultations prior to decision-making. Mechanisms designed to ensure public accountability are thus very limited. The lack of such rules is not compensated for by the possibility given to citizens to refer a matter to the European Ombudsman. The latter has proven its usefulness, but his intervention is limited to cases of "maladministration" by the agencies. $^{238}$

\section{"Performance" Accountability}

\footnotetext{
${ }^{233}$ See Report of the French Council of State, supra note 20 at p.367.

${ }^{234}$ See Article 39 of the proposed regulation establishing a European Railway Agency, supra note 161.

${ }^{235}$ See, for instance, R. Baldwin and M. Cave, supra note 47 at p.287. See Alison Young, The Politics of Regulation - Privatized Utilities in Britain, (2001) Palgrave at p.108. See W. Smith, supra note 22.

${ }^{236}$ This is the case of the Regulation establishing the EASA (see Article 29). However, it must not be forgotten that the classic mechanisms of parliamentary questions remain available. In such hypothesis, controls would only take place on a non regular basis. Hence, the Commission has proposed that agencies be submitted to regular parliamentary hearings. See Communication from the Commission on the Operating Framework for European Regulatory Agencies, supra note 18 at p.13.

${ }^{237}$ See Jean-Paul Fitoussi, La Règle et le Choix, September 2002, Le Seuil.

${ }^{238}$ The Ombudsman enjoys limited powers. It is, however, reported that his influence over the EC agencies has been significant. Pursuant to one of his recommendation, some agencies were brought to adopt their own code of conduct. See E. Vos, supra note 4 at p. 1128. See also press release 5/2000 of 30 March 2000. On the European Ombudsman, see Gjerloeff Bonnor, "The European Ombudsman: a Novel Source of Soft Law in the European Union”, (2000) 25 European Law Review, 39.
} 
Finally, the absence of a regular assessment mechanism of the regulatory activity of EAs is regrettable. In fact, the impact of the regulatory activity in terms of indirect socioeconomics costs and benefits should be examined regularly. This would first help in determining whether the entity has acted efficiently or has failed to implement efficient solutions. ${ }^{239}$ In this case, improvements of the regulatory output would be required. Review procedures of that kind have been implemented in the US, where the Office of Information and Regulatory Affairs (the "OIRA") is in charge of the assessment of regulatory programmes and of Regulatory Impact Analysis. ${ }^{240}$ This solution has also been implemented in some MS such as France, where "Parliamentary Offices of Assessment of Legislation and of Public Policies" are carrying out regular reviews of the policies implemented by the IAA. ${ }^{241}$ Interestingly, some of the new constituent regulations provide for an "evaluation" instrument pursuant to which the functioning, as well as the regulatory outcome of the agency have to be assessed after a varying period of time. ${ }^{242}$ This procedure should be generalized to all agencies.

\subsubsection{Lack of transparency}

Article 255 of the EC Treaty, which provides for a general right of access to documents of the Commission, the Council and the EP, is not clear as to whether EAs have to communicate the documents produced in the regulatory process. ${ }^{243}$ However, Regulation 1049/2001 regarding public access to European Parliament, Council and Commission documents explicitly provides for its application to the EAs. ${ }^{244}$ In addition, the constituent regulations setting up the most recent agencies provide for the application of

\footnotetext{
${ }^{239}$ Such a review would also permit to assess whether the existence of an agency remains justified. Some agencies have been set up to remedy a contextual problem. They may thus be regularly assessed in order to determine whether the objective assigned has been achieved. The maintenance of an agency after its mission has been accomplished involves unnecessary costs for society.

${ }^{240}$ In the US, the OIRA reviews the agencies output on the basis of a cost/benefits analysis. For a good description of the OIRA, see Alfred C. Aman Jr., Administrative Law and Process, (1993) Mathew Bender, Casebook series at p. 634. See also, Alfred C. Aman Jr. and William T. Mayton, Administrative Law, (1993) West Publishing at pp.567-570.

${ }^{241}$ See Report of the French Council of State, supra note 20.

${ }^{242}$ See Article 51 of the regulation establishing the EASA and Article 27 of the regulation establishing the EMSA, supra note 160 .

${ }^{243}$ On the right of access to documents, see Marc Schauss, "L'accès du citoyen aux documents des institutions communautaires", (2003) 1 JTDEuropéen, 1; Morten Broberg, "Access to Documents : A General Principle of Community Law”, (2002) 27 European Law Review, 194; Deirdre Curtin, “Citizen's Fundamental Right of Access to EU Information: an Evolving Digital Passepartout?", (2000) 37 Common Market Law Review, 7. Article 255 has been inserted by the Treaty of Amsterdam. Prior to this, there was no mandatory requirement for EAs to grant access to their documents. Most agencies had nevertheless adopted decisions on the access to their own documents. It has been considered that these rules were not satisfactory because they are based on the Commission's own rules, which consist of a "long and obscure list of possible reasons to deny access to documents". See E. Vos at note 70, supra note 4.

${ }^{244}$ See Regulation 1049/2001 of the European Parliament and of the Council of 30 May 2001 regarding public access to European Parliament, Council and Commission documents, OJ L 145 of 31 May 2001 p.43 at recital 8 of the preamble: "In order to ensure the full application of this Regulation to all activities of the Union, all agencies established by the institutions should apply the principles laid down in this Regulation."
} 
Regulation 1049/2001 to their own activities pursuant to arrangements decided by the management board. ${ }^{245}$ This new regime is thus to be welcomed.

Transparency also implies a certain degree of clarity and simplicity of the regulatory processes. $^{246}$ In this respect, the degree of transparency of certain EAs is far from ideal since much of the regulatory work is carried out by opaque committees. This can be illustrated by the functioning of the EMEA. Its processes involve four different kinds of actors. ${ }^{247}$ First, the EMEA is composed of two committees (the CMPP and the CVMP), which are in turn assisted by working parties that provide advice on specific issues and in some instances, specialized ad hoc groups can be set up to address particular matters. ${ }^{248}$ Second, the agency is expected to cooperate with several trans-national committees. Third, some issues have to be dealt with by the EMEA in cooperation with the national authorities. Fourth, the decision-making powers belong to the Commission. Hence, the combination of these levels of intervention, the composition of the committees, as well as their precise functioning is obscure. Many improvements could be achieved in this regard.

Finally, the creation of EAs besides the Commission may result in increased confusion over their respective competences, as well as overlaps between their respective activities. The lack of a clear allocation of competences between the EAs and the Commission may in turn prejudice the interests of stakeholders in terms of legal certainty as the agencies and the Commission may both adopt measures addressing a similar matter (with the resulting risk of conflicts) or decide not to act considering that the other entity is the competent institution (with the resulting risk of leaving a matter unaddressed). For instance, a clash between the Commission's environment directorate general and the EEA over the roles each should play in environmental policy making has recently been reported. ${ }^{249}$ It is thus suggested that the constituent regulations should better define the competences of the EA in relation to those of the Commission. In addition, similar conflicts of competences among EAs or between EAs and various committees involved in comitology processes cannot be ruled out. However, the Commission seems to now take steps to prevent such conflicts. In its proposal for the creation of a European Chemicals Agency, the Commission proposes the adoption of a provision dealing with the "conflicts of opinion with other bodies". ${ }^{250}$ Pursuant to this provision, the ECA shall ensure early identification of potential areas of conflicts with other bodies. In case of conflict, it shall enter into cooperation with the conflicting body, exchange all relevant information and work out solutions to end it. Finally, if the conflict persists, there is a

\footnotetext{
245 See Article 47 of Regulation 1592/2002 instituting the AESA, supra note 160. See Article 4 of Regulation 1406/2002 instituting the EMSA. Curiously, the wording of Regulation 178/2002 instituting the EFSA is slightly different and does not make reference to Regulation 1049/2001.

246 See Amaryllis Verhoeven, "The Right to Information: a Fundamental Right" in An Efficient, Transparent Government and the Rights of Citizens to Information, European Institute of Public Administration, Maastricht 29-30 May 2000, at p.1.

${ }^{247}$ See E. Chiti, supra note 4 at p. 320 .

${ }^{248}$ Furthermore, the Committees may decide to be assisted by experts working on behalf of the EMEA from a list established by the MS.

${ }^{249}$ See Environment Watch, 13 October 2003, p.12.

${ }^{250}$ See Article 92 of the Proposal for the creation of a European Chemicals Agency, supra note 3.
} 
possibility to refer a joint document to the Commission which seems to be given the last say over the conflict.

\subsubsection{Lack of participation}

Stakeholders, civil society and professional bodies are insufficiently involved in the decision procedures of the agencies. No mandatory requirements are set up in this respect and the extent of public participation solely depends on the agencies' own commitment. This lack of participation may prove counter-productive. ${ }^{251}$ Indeed, the participation of stakeholders in the adoption of regulatory decisions involving technical matters presents several advantages. First, in highly specialized fields, it tends to help address the problem of asymmetry of information (between regulatory institutions on the one hand, and economic operators on the other hand), and it helps to ensure that the practical consequences of decisions are well evaluated. Second, the implementation of regulatory decisions is likely to be better accepted by its addressees if the body that has taken the decision is composed of well recognized and informed professionals.

Better participation can be achieved through a variety of measures. For instance, the insertion within the constituent regulation of professional criteria for the appointment of the Members of the Management board and of representation rules (i.e., rules ensuring some representation of each of the relevant category of stakeholders subject, however, to the limits placed in the next paragraph) could be a positive measure. ${ }^{252}$ In addition, participation may be improved by the organization of conferences, workshops, regular meetings, preliminary consultations (under the form of green papers, call for comments etc.), as well as the posting of draft documents on the Internet with the possibility to comment. $^{253}$

Some authors have, however, raised the argument that participation could expose the agencies to the risk of capture. ${ }^{254}$ As far as public consultation is concerned, authors argue that the participation should be restricted to the granting of observers' status as well as right to be heard. If participation in the decision-making process was to be authorized (which is not necessarily a desirable option), rules ensuring rapid turnover in professional group representatives should be at least adopted. ${ }^{255}$ Second, as far as the composition of the management board is concerned, risks of capture could result from the appointment of representatives of the economic operators that may, during their mandate, attempt to influence decisions in favour of their firms. It is thus preferable to hire people with experience in the private sector, but which have no longer any tie with industry interest.

\footnotetext{
${ }^{251}$ The degree of participation varies with the agencies. Some agencies include representatives from the public in their decision-making structures (EU-OSHA), while others rely on voluntarily mechanisms such as conferences and meetings (EEA). Finally some agencies do not really involve stakeholders in their activities.

${ }_{252}^{25}$ See Report of the French Council of State, supra note 20 at p.317 and following.

${ }^{253}$ Such methods are intensively used in the field of competition. The Commission's Directorate General for Competition has developed an important number of mechanisms for improving participation of the interested parties.

${ }^{254}$ See M. Everson, supra note 4, p.201

${ }^{255}$ See Id.
} 
One should also note, however, that the risks of capture may also exist with civil servants, especially if nothing is done to prevent revolving doors practices. ${ }^{256}$ In any of both instances, and provided that proper measures are adopted to prevent conflicts of interest, the involvement (internalization) of interest groups in the decision-making process may have a positive signalling effect (credibility, openness and concern) vis-à-vis the operators thereby reducing the incentives for lobbying and other forms of external pressures.

\section{Fine tuning the institutional regulatory parameters for EAs}

The analysis of the institutional regulatory parameters shows that there is a case for advocating several adjustments.

\subsection{Improving the test for choosing to form EC wide agencies}

As we have seen above, there are some areas in which the absence of EAs is regrettable as these areas raise problems of a European dimension. Moreover, the coordination mechanisms on which the Commission is relying to address some of the problems generated by the absence of a regulatory body are either not completely satisfactory (e.g. the Florence and Madrid fora) or create unnecessary complex institutional framework (e.g., the cooperation networks set up by the Commission). On the other hand, we believe that the Commission has perhaps proposed the creation of too many agencies. We have, for instance, identified a number of EAs, the creation of which was probably not warranted and would not pass a rigorously administered test of subsidiarity.

We thus believe that, before creating EAs or ordering the MS to create NRAs, the EC should engage in a rigorous analysis, the purpose of which would be to determine the optimal level of regulatory intervention. This analysis should be based on the criteria offered by the economic analysis, which we have described above.

\subsection{The need for more homogeneity}

At the European level, the current lack of institutional homogeneity with respect to the EAs gives an impression of chaos. ${ }^{257}$ We believe, however, that the situation could be improved through two complementary initiatives. First, as we have suggested above, the Commission should adopt a regulation, which we propose to call EAPR, to clarify the status of the different agencies around three simple categories: the executive agencies, the decision-making agencies and the regulatory agencies. Second, this regulation should provide a framework for all procedural and organizational requirements applicable to EAs, as well as provide for good governance requirements (this latter issue will be

\footnotetext{
${ }^{256}$ This could be done with the adoption of a rule of 'incompatibility', e.g. the provision that, for a number of years, members of the board commit themselves not to be employed within the industry, in the sectors that are regulated by the agency.

${ }^{257}$ Although the provisions instituting recent agencies prove, to a certain extent, that there is a degree of convergence, the case by case legislative approach to the setting up of agencies results in an important heterogeneity, even for agencies operating in close sectors. See the conclusions of L. Grard on the EMSA and on the EASA, supra note 4 at p.7,
} 
addressed in the next section). ${ }^{258}$ As we have seen, both sets of requirements would, however, sometimes vary depending on the category of EAs concerned.

In substance, such a regulation would create a procedural framework for these agencies, minimum standards of transparency and accountability, and provide for the harmonization of basic features of these entities. Ideally, this regulation would include rules governing consultation of the interested parties prior to regulatory action, publicity of the acts, duties to give reasons, duties to consult the public, time limits for the adoption of rules, remedies for challenging decisions, publications of annual reports, budgetary transparency and, finally, rules on incompatibility, staff recruitment, contracting with third parties etc.

Several options would be available with regards to the legal basis of such an act. By analogy with Regulation 58/2003, one could rely on Article 308. We believe, however, that is would not be the best option. This provision only requires the consultation of the EP in the legislative process. The input of the EP on the wording of the EAPR would thus be limited. In addition to a "legitimacy" deficit, this could lead to inconsistencies as the EP has gained an important say in the subsequent setting up of agencies, with the increasing recourse to specific legal basis in the EC Treaty that most of the time require co-decision.

\subsection{Improving compliance with principles of good governance}

The state of compliance of EAs with principles of good governance is rather unsatisfactory. However, in recent times, several improvements have been observed and it seems that EC institutions are feeling increasingly concerned with issues of good governance. This is illustrated by the statutory obligations imposed on the recently created EAs, which require them to comply with a number of good governance principles (e.g. periodic review, consultation and openness mechanisms etc.). For a variety of reasons, this approach is, in our view, insufficient. First, the insertion of these new principles only affects the newly created agencies. The first and second wave agencies remain bound by old rules and are not bound to apply such principles. This, in turn, leads to the apparition of a gap among the agencies whereby some apply modern governance principles, while other are exempted from them. Second, the governance requirements included by new generation constituent regulations remain too limited. For instance, the provisions of the recent constituent regulations generally fail to provide sufficient requirements regarding the assessment of regulatory outputs. ${ }^{259}$

\footnotetext{
${ }^{258}$ Already in 1993, the EP had raised concerns about the great heterogeneity of agencies and had invited the Commission to elaborate a "statut cadre" for the EAs. The EP, in that regard, had established a list of nine essential requirements for the agencies to comply with. See Resolution of the European Parliament, A3-0414/92 of 19 January 1993, supra note 49. A number of authors have shown support to the adoption of a European Administrative Procedural Act. See X. Yataganas, supra note 4 at p.47. See M. Everson, supra note 4 at p.201.

${ }^{259}$ First, some agencies are submitted to the centralized evaluation of the Commission (e.g. the proposed European Railway Agency), to evaluation of the Commission in collaboration with the board of the agency (e.g. the EFSA or the NISA) or to evaluation by an independent external body (EASA or EMSA). Second, the periods provided for are different: three years for the EASA and for the NISA, five years for the EMSA
} 
For these reasons, it is suggested that a more transversal approach should be explored. This is not the approach suggested by the Communication on the Operating Framework for the European Regulatory Agencies. The Commission supports that the application of the EC Treaty rules (e.g. Article 253, Article 255 etc.) and a variety of secondary legislation instruments simply be extended to EAs. ${ }^{260}$ The latter approach lacks clarity and simplicity as these provisions are disseminated in a large number of different instruments. Thus, as we suggest in the prior section, the preferred approach is for the EAPR to contain a section dealing with good governance principles. Indeed, we believe that such principles have to be given serious consideration in the creation of subsequent operation of the EAs.

\section{Conclusion}

The creation of a growing number of agencies at both national and European levels is one of the most significant developments in the administrative structure of the EC and its Member States. These agencies have generally played a useful role. While NRAs have contributed to the creation of competitive markets in liberalized sectors, EAs have allowed the Commission to decentralize a number of scientific, technical or observatory functions to specialised bodies. Yet, we believe that several steps could be taken to enhance the methods of functioning of these agencies with a view to improve their performance, as well as to ensure a greater degree of coherence in the way they are organised, interact with each other, and comply with good governance principles.

First, we believe that the Commission should re-open the debate over the creation of European Regulatory Agencies in areas, such as telecommunications or energy. Such sectors involve a range of cross-border regulatory matters, which cannot be satisfactorily addressed by the NRAs, with a resulting lack of coherence in the internal market. In order to overcome the restrictions imposed by the Meroni doctrine, and in the absence of an ECJ judgment overruling this doctrine, we believe that an amendment to the Treaty would be desirable.

Second, as NRAs will continue to play an important role even if European Regulatory Agencies were to be created (as they would be in charge of implementing the European Regulatory Agencies' policies and decisions, as well as dealing with regulatory issues of a national character), we would encourage the European Commission to adopt a set of guidelines providing for best practices in the institutional and procedural aspects of regulation, as well as best practices in the area of good governance. This would allow a greater degree of homogeneity of regulatory processes among Member States, while leaving them the flexibility to pursue institutional experimentation.

and for the proposed European Railway Agency, six years for the EFSA. Third, the board is generally entitled to issue recommendations for changes on the basis of the evaluation results. However, while in some instances, the Commission may forward these recommendations to the Council and the EP (EASA), in other instances, it is obliged to do it (EMSA), and in some other cases no rules are provided for (e.g. the EFSA).

${ }^{260}$ See Communication on the Operating Framework for the European Regulatory Agencies, supra note 18. 
Third, we believe that the Commission should devote more time and energy to the issue of classification of EAs, as well as the procedural regimes applicable to them. The classification proposed by the Commission in its Communication on the Operating Framework for the European Regulatory Agencies fails to convince and risks introducing additional confusion on an issue that is already plagued by conceptual inconsistencies. We thus suggest that the Commission should opt for our proposed classification pursuant to which EAs would be divided into three categories: (1) the "executive" agencies, which would comprise all European agencies that are responsible for (i) purely managerial tasks (e.g., the EAR, the ETF and the CdT), or (ii) observatory roles (the EEA, the EMCDDA, and the EUMC), or (iii) missions of cooperation (e.g., the Cedefop, the Eurofound or the EU-OSHA); (2) the "decision making" agencies, which would comprise all agencies that have the power to enact legal instruments binding on third parties (e.g. the OHIM, the CVPO, the EASA) or of the agencies that without enjoying a formal decision-making power, in fact enjoy a considerable influence over the adoption of final decisions by the Commission (e.g. the EMEA, the EFSA and possibly the EMSA); and (3) the "regulatory" agencies, which would comprise all European agencies that enjoy the types of powers enjoyed by the NRAs, including a discretionary power to translate broad legislation guidelines into concrete instruments. As far as the procedural regime applicable to the these agencies is concerned, we suggest that the Commission should expand Regulation 58/2003 to our proposed category of decision-making authorities, which would then deal with both executive and decision-making agencies. Ideally, this new expanded regulation, which we would refer to as the European Agencies Procedural Regulation (EAPR), would not only deal with the organizational and procedural matters dealt with by Regulation 58/2003, but also to good governance principles, the importance of which is increasingly significant. 